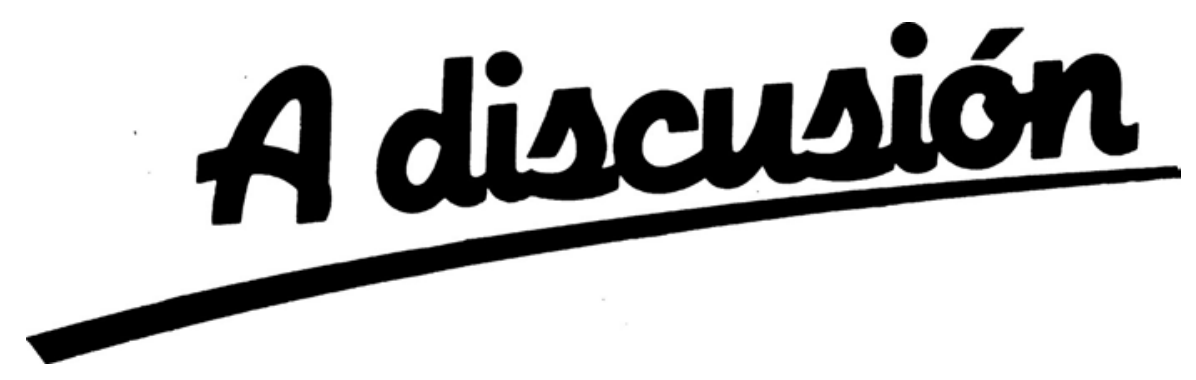

\title{
RICH, POOR AND GROWTH-MIRACLE NATIONS: MULTIPLE EQUILIBRIA REVISITED*
}

\section{Dmytro Kylymnyuk, Lilia Maliar and Serguei Maliar**}

WP-AD 2004-39

Corresponding author: Lilia Maliar, Departamento de Fundamentos del Análisis Económico, Universidad de Alicante, Campus San Vicente del Raspeig, Ap. Correos 99, 03080 Alicante, Spain. E-mail:maliarl@merlin.fae.ua.es

Editor: Instituto Valenciano de Investigaciones Económicas, S.A.

Primera Edición Octubre 2004.

Depósito Legal: V-4396-2004

IVIE working papers offer in advance the results of economic research under way in order to encourage a discussion process before sending them to scientific journals for their final publication.

\footnotetext{
* We thank Lola Guilló and Fidel Pérez for valuable comments. This research was supported by the Instituto Valenciano de Investigaciones Económicas, the EERC Consortium and the Ministerio de Ciencia y Tecnología de España, the Ramón y Cajal program and BEC 2001-0535.

** D. Kylymnyuk: University of Toulouse. L. and S. Maliar, Departamento de Fundamentos del Análisis Económico, Universidad de Alicante, Campus San Vicente del Raspeig, Ap. Correos 99, 03080 Alicante, Spain.E-mail: maliarl@merlin.fae.ua.es
} 


\title{
RICH, POOR AND GROWTH-MIRACLE NATIONS: MULTIPLE EQUILIBRIA REVISITED
}

\author{
Dmytro Kylymnyuk, Lilia Maliar and Serguei Maliar
}

\begin{abstract}
This paper presents a two-sector growth model of international trade that can account for the key features of the postwar world development experience. Two sectors represent the traditional primitive production and the modern sophisticated production. Due to increasing returns in the modern sector, the open-economy version of our model gives rise to three different equilibria: one in which the country produces only primitive goods and converges to a low-income steady state; another in which it produces both primitive and sophisticated goods and converges to the world-average steady state; and a third in which it specializes in the production of sophisticated goods and converges to a balanced growth path. We argue that the development experiences of poor, rich and growth-miracle countries are well described by these three equilibria.
\end{abstract}

JEL Classification: C00, F12, O14, O30, O41

Key words: International trade, small-open economy, multiple equilibria, poverty trap, growth miracles, coordination proble 


\section{Introduction}

In this paper, we attempt to develop a unified theory that accounts for the main features of the postwar world development experience. The regularities that we observe in the data and that we try to reproduce are as follows: The typical rich country has a relatively large industrial sector and a relatively small agricultural sector, a sectorial composition that becomes stable over time. Rich countries have generally been rich for quite a long time and now continue growing at relatively moderate rates. Some rich countries are large while others are small. The typical poor country, on the other hand, specializes in the primitive natural-resource-based production and exchanges its primitive products (agriculture, food, fuel, ore, etc.) for more sophisticated products (manufactured goods) on the international market. Most of the poor countries have been poor for a long time and continue to have small positive or even negative growth rates. However, some of the countries that were poor in 1950s have started to grow at very high rates. The period of fast growth in such growth-miracle countries has been accompanied by a dramatic increase in their industrial sectors (especially, in machinery and high-tech) relative to that of agriculture. Over the postwar period, the growth-miracle countries changed their international specialization, becoming importers of primitive goods and large-scale exporters of manufactured goods of increasing sophistication.

Our theory, aimed at explaining the above empirical regularities, is built around a dynamic two-sector growth model of international trade. The first sector produces a primitive commodity by using a constant returns-to-scale technology with two inputs, capital and natural resources, with the latter input being available at a fixed level. The second sector produces a sophisticated commodity from capital and primitive commodities; its technology has increasing returns in the early development stages (due to learning-by-doing 
and knowledge externalities), and it has constant returns in its later development stages (due to bounded externalities). Only sophisticated commodities can be used for consumption and investment. We consider two different variants of our economy, the autarkic and the open-economy versions. In the latter case, we assume that both primitive and sophisticated goods are tradable on the international market and that the economy is small in economic terms, so that it does not affect world prices.

In the autarkic version of our economy, long-run growth is impossible. Since the amount of natural resources is fixed, there are decreasing returns to scale in the production of primitive goods, and since primitive goods are used as an input for producing sophisticated goods, there are also asymptotically decreasing returns to scale in the production of sophisticated goods, which implies that the autarkic economy converges to a steady state.

The open-economy version of our model gives rise to three different equilibria, which are referred to here as the "poverty-trap", the "autarky-like" and the "growth-miracle" equilibria. In the poverty-trap equilibrium, the country produces only primitive goods and trades them for sophisticated goods on international market; it converges to a steady state with consumption (welfare), which is lower than that of the autarkic economy. Furthermore, in the autarky-like equilibrium, the open economy produces both primitive and sophisticated commodities; it mimics the behavior of the autarkic economy and converges to the same steady state as the autarkic economy does. Finally, in the growth-miracle equilibrium, the country produces mainly sophisticated goods and trades them for primitive goods on international market; it converges to a balanced growth path with an asymptotically constant growth rate. Long-run growth is possible for a small open economy because it can buy primitive goods at a constant world price and thus, has constant returns to the production of sophisticated goods. We argue that the postwar development experience of poor, rich and fast-growing countries 
is well described by the three equilibria we have constructed. ${ }^{1}$

When choosing equilibrium, the agents face a coordination problem. In particular, because the production of sophisticated goods would be unprofitable for an individual investor if no other investors entered this sector, but it would be profitable if enough investors do so. ${ }^{2}$ Therefore, according to our theory, countries that perform well are those that succeed in coordinating on achieving a good equilibrium. We show that a larger capital endowment or richer natural resources can facilitate convergence to a good equilibrium. However, even under the most favorable initial conditions, a country can get stuck in a bad equilibrium forever. We argue that the government is the natural candidate for the coordinating task. In fact, empirical evidence indicates that government policies inducing simultaneous entry of producers into the sophisticated-goods sector, played a crucial role in the economic success of the actual growth-miracle countries.

Our model combines several features that have been repeatedly referred to in the literature as being important in explaining the determinants of the economic growth and prosperity of nations. First of all, our model is similar to Variable-Returns-to Scale (VRS) models of international trade, in its assumption of increasing returns to scale in one of the two production sectors. ${ }^{3}$ This assumption leads to multiple solutions in our model, as it does in the typical VRS setup. ${ }^{4}$ Our model is particularly close to the one in Matsuyama (1992), however, there is an important difference between the two

\footnotetext{
${ }^{1}$ The presence of multiple equilibria has long been used in the literature to explain wide income differences across countries. As was advocated by Lucas (1993, p. 269), "If our objective is to understand a world in which similarly situated economies follow very different paths, these theoretical features [multiplicities] are advantageous".

${ }^{2} \mathrm{~A}$ similar mechanism lies in the basis of the model of industrialization by Murphy, Shleifer and Vishny (1989). See also Rodrick (2003) for a discussion of the literature where coordination failures are induced by increasing returns to scale, as is in our case.

${ }^{3}$ See Choi and $\mathrm{Yu}(2002)$ for a review of the VRS trade literature.

${ }^{4}$ See Kemp and Schweinberger (1991) for a discussion on the multiplicity of equilibria in the VRS class of models.
} 
models: we explicitly consider intertemporal capital accumulation, whereas Matsuyama (1992) assumes that the capital input is fixed. ${ }^{5}$ Thus, unlike the previous VRS models, which either have no engine of long-run growth and predict convergence to a steady state (as in, e.g., Graham and Temple, 2003) or have an exogenous engine of long-run growth (as in Matsuyama, 1992), our model can generate balanced endogenous long-run growth. ${ }^{6}$

Furthermore, in the growth-miracle equilibrium, our economy is similar to Hansen and Prescott's (2002) economy which evolves from agriculture, with a decreasing-returns-to-scale technology, to industry with $A K$ technology. We differ from Hansen and Prescott (2002) in several respects. They focus on the closed-economy case, assume that the goods produced by the two sectors are perfect substitutes and do not consider externalities, which implies that there is a unique equilibrium where industry is always opened as soon as enough capital is accumulated. In contrast, we concentrate mainly on the open-economy case, assume that the output of one sector is used as the input for the other, and we have multiple equilibria, due to the presence of externalities, which implies that opening of the sophisticated-goods sector is not guaranteed in general.

Finally, our model is closely related to the dynamic neoclassical HeckscherOhlin models of comparative advantage, considered in Ventura (1997) and Atkeson and Kehoe (2000). We share with Ventura (1997) the mechanism for making a miracle, i.e., the implication that a small open economy that faces constant world prices can behave as if it had a linear technology. However, in contrast to Ventura (1997), who generates differing economic performance

\footnotetext{
${ }^{5}$ Matsuyama (1992, p. 330) admits that neglecting capital accumulation is "probably the most serious omission" of his analysis.

${ }^{6}$ Our model is also related to closed-economy models of industrialization where there exist multiple equilibria due to increasing returns in the industrial sector; see, e.g., Murphy, Shleifer and Vishny (1989), Matsuyama (1991). However, those models do not generate endogenous long-run growth either.
} 
of simultaneously developing countries by assuming ex-ante heterogeneity (in, e.g., rental rates, relative productivities of sectors, subjective rates of preferences across countries), we have cross-country differences due to the multiplicity of equilibria, even if all of the countries are ex-ante identical. We share with Atkeson and Kehoe (2000) the assumption that countries differ in their timing of development. To be more specific, we assume that a small open economy begins to develop when the rest of the world has already developed. However, our conclusions regarding the destiny of a small late-blooming country is different from that of Atkeson and Kehoe (2000): their model predicts that late-blooming countries necessarily converge to a lower level of output per capita than early-blooming countries do, whereas our analysis suggests that late-blooming countries can converge either to a steady state with lower output than early-blooming countries do, or to a steady state with the same output as early-blooming countries do, or to a balanced growth path.

The plan of the paper is as follows: In Section 2, we describe the empirical relationship between the sectorial composition, international trade and economic growth. In Section 3, we present the model and characterize its implications, and we argue that the predictions of our model are consistent with actual world development. In Section 4, we discuss some factors that determine the equilibrium choice, and finally, in Section 5, we conclude.

\section{Sectorial composition, international trade and economic growth: the stylized facts}

In this section, we investigate the relationship between sectorial composition, international trade and economic growth by performing a cross-country comparison. We use the World Development Indicators CD-ROM (2000) data set, which contains relevant information for the period 1960-1999. For our 
study, we select a sample of 100 countries for which the data on GDP are available for at least the entire period 1965-1994. In the ranges 1960-1964 and 1995-1999, several values were missing for the GDP of such countries as Canada, Malta, Oman, Puerto Rico and Congo D. R. We restored the missing values by a linear extrapolation of a logged GDP on a constant and time trend. We provide a list of the countries in our sample in Table 1. Furthermore, for both the first year, 1960, and the last year, 1999, we report each country's size (defined as its share of the total GDP of the sample), its GDP per capita and its rank according to GDP per capita. Finally, we provide each country's cumulative GDP growth rate over the 1960-1999 period (defined as the ratio of GDP in 1999 to that in 1960) and its rank according to the cumulative growth rate of the GDP.

We use the constructed rankings to distinguish three groups of countries: a group of "rich" countries which is composed of the top ten countries in the sample by the level of GDP in 1999 (Luxembourg, Switzerland, Japan, Norway, Denmark, Austria, U.S., Iceland, Netherlands and Finland); the group of "fast-growing" countries which includes the top ten countries in the cumulative GDP growth over the 1960-1999 period (Botswana, Singapore, South Korea, Malta, Oman, Hong Kong, China, Thailand, Japan and Malaysia) and the group of "poor" countries which consists of the bottom ten countries in the level of GDP for 1999 (Nigeria, Madagascar, Rwanda, Chad, Nepal, Niger, Malawi, Sierra Leona, Burundi and Congo D.R.). Given that six out of the ten poorest countries belong to the group of the ten slowest-growing countries, (specifically, Madagascar, Rwanda, Chad, Niger, Sierra Leona and Congo D.R.), we shall not distinguish between the groups of poor and slowgrowing countries, but rather focus exclusively on the former group. In Table 2, we report the key statistics on the GDP and export for our three groups of countries as well as for the whole sample (the shares are the averages over the 1990-1999 period and the growth rates are the averages for 1960-1999). As 
a test for robustness, we also report the same set of statistics by increasing the size of the rich, fast-growing and poor groups from ten to twenty. In Table 3, we provide evidence on the composition of international trade, by products, for our set of countries obtained from the World Factbook (2002). In Figures 1, 2 and 3, we draw, respectively, the shares of industry and agriculture in GDP, the sectorial composition of manufacturing and the sectorial composition of export, for the three groups of countries distinguished. ${ }^{7}$

We summarize the tendencies observed in the data below.

1. The richest countries are not the ones with the highest growth rates, and the fast-growing countries are not particularly rich.

2. In general, fast-growing countries are small. Rich countries may be either large or small.

3. The rich countries have large industrial sectors and small agricultural sectors, and the poor countries have large agricultural sectors and small industrial sector. The shares of industry and agriculture in both the rich and poor countries are stable over time. The fast-growing countries first had large agricultural sectors and small industrial sectors, as the poor countries do. Over the subsequent period of fast growth, the fastgrowing countries experienced a dramatic reduction of their agricultural sectors and a great expansion of their industrial sectors.

4. For the rich countries, the largest component of manufacturing is machinery, whereas for the poor countries, it is food (and the smallest

\footnotetext{
${ }^{7}$ Whenever data for a country is unavailable, we replace such a country in Figures 1-3 with its nearest out-of-group neighbor for which data is available. As a result, in some figures, we have the series for Belgium, Finland and Burkina Faso, which according to GDP in 1999, occupy the 11th, 12th and 90th places, respectively. Furthermore, given that Japan enters both the rich and the fast-growing groups, we replace it with Indonesia, which is the 13th fast-growing country.
} 
component is machinery). For the fast-growing countries, the share of machinery in manufacturing was initially small but increased dramatically over the period of fast growth.

5. The poor countries are heavy net exporters of primary products (i.e., fuel, ore, food and agriculture) and net importers of highly elaborated products (manufacturing). The rich countries do not have a pronounced pattern of international trade. The fast-growing countries increase the share of manufacturing in their net exports over the period of fast growth. In particular, the fast-growing countries have the highest share of high-tech export in GDP.

Let us discuss the above stylized facts in greater detail. As far as Fact 1 is concerned, the growth-rates ranking among the ten richest countries are 21 , $59,9,18,45,27,44,26,41$ and 25, respectively (see Table 1). The average growth rate of the rich group is $2.78 \%$, which is much lower than the growth rate of the fast-growing group, $5.52 \%$ (see Table 2 ). In turn, the ranks by GDP per capita in 1999 of the ten fast-growing countries are 45, 14, 28, 29, $35,17,72,50,3$ and 41 , respectively. In 1960, the GDP per capita of the fast-growing group was about twice as low as the sample average and more than six times as low as that of the rich group. As a result of their continuous fast growth, in 1999, the GDP per capita of the fast-growing group surpasses that of the sample average, but is still about three times as low as that of the rich group. In fact, there is only one country, Japan, which belongs to both the rich and the fast-growing groups.

As regards Fact 2, the sizes of seven out of ten fast-growing countries, such as Botswana, Singapore, Malta, Oman, Hong Kong, Thailand, and Malaysia were less than $20 \%$ of the sample average in 1960, and remain far below the sample average in 1999 in spite of their continued economic growth (see Table 1). South Korea and China had their initial sizes comparable to the 
sample average ( $48 \%$ and $113 \%$, respectively) and increased their sizes to $187 \%$ and $330 \%$, respectively, in 1999. Japan is the only serious exception to the general rule: it was about ten times larger than the sample average in 1960, and it almost doubles its relative size in 1999. Furthermore, our rich group is composed of six countries whose sizes are about average in both 1960 and 1999 (Norway, Finland, Austria, Netherlands, Denmark, Switzerland), of two very large countries (Japan and the U.S), and of two very small countries (Luxembourg and Iceland). Thus, the size of the typical fast-growing country is significantly smaller than that of the typical rich country.

The tendencies listed in Fact 3 are illustrated in Figure 1 and are quantified in Table 2. As can be seen from the table, the shares of industry in GDP for the rich, fast-growing and poor groups are about $27.9 \%, 40.5 \%$ and $22.1 \%$, respectively, whereas the shares of agriculture in GDP for these groups are about $3.8 \%, 6.8 \%$ and $37.2 \%$, respectively. (The figures for the shares of labor employed in industry and in agriculture are quite similar). Furthermore, in the fast-growing countries, the growth rate for industry is $7.7 \%$, which is remarkably higher than it is for either the rich or the poor countries, $2.2 \%$ and $0.9 \%$, respectively. The growth rates for agriculture are, in general, low and do not differ substantially among the fast-growing, rich or poor groups, amounting to $0.7 \%, 0.7 \%$ and $0 \%$, respectively. In Figure 1, we observe few exceptions to the regularities in Fact 3. Specifically, for such fast-growing countries as Singapore, Malta and Hong-Kong, the agricultural sector had always been nearly zero because of their poor endowment of land. In Congo D.R., the share of agriculture was initially smaller than that of industry, however, it increased over the last decade and currently exceeds the share of industry.

The regularities in Fact 4 can be readily seen from Figure 2 and Table 2. In particular, it follows from the table that the growth rate of machinery in the fast-growing countries was $18.3 \%$, which is much higher than that in 
the rich countries, where it is $3.0 \%$. Currently, the share of machinery in GDP in the fast-growing countries is almost twice as much as it is in the rich countries. In the poor group, machinery was also growing at a high rate of 12.4\%. However, given that, initially, this sector was almost non-existent, its share in GDP still represents just $0.8 \%$. It is interesting to note that the evolution of machinery in Japan is quite characteristic for both rich and fastgrowing countries: machinery was the largest part of manufacturing sector in Japan, as it is in the rich countries, and it has been growing rapidly, as it is in the fast-growing countries. This substantiates the fact that Japan belongs to both the rich and the fast-growing groups.

To appreciate the composition of the exports and imports of the different countries listed in Fact 5, we shall look at Figure 3, Table 2 and Table 3. Regarding the rich group, we observe that some countries, like Luxembourg, Switzerland, Japan and Finland are net exporters of manufactured goods and importers of primary goods; other countries that are particularly rich in certain primary goods, like Denmark (fish, meat), Norway (petroleum), Iceland (fish) and Netherlands (food), are importers of manufactured goods and exporters of primary goods; finally, Austria and the U.S. are currently importers of both primary and manufactured goods (see Figure 3 and Table 3). The fact that the fast-growing countries experienced a large expansion in the export of manufactured goods over the last two decades can be observed from Figure 3: initially, such countries as China, Thailand, Malaysia and Indonesia were importers of manufactured goods and are now net exporters; and South Korea increased its share of net exports of manufactured goods in its GDP, from $7 \%$ to $20 \%$. In particular, the gross export of high-tech products in the fast-growing group is $7.58 \%$ of their GDP, which is much higher than the respective numbers for the rich and the poor groups, $2.78 \%$ and $0.04 \%$, respectively. (Unfortunately, we do not have data on net export of high-tech products). Finally, there is a very clear pattern of international 
trade for the poor countries which export such primary goods as cotton, livestock, coffee, tea, carpets, tobacco, sugar, peanuts, petroleum or diamonds in exchange for capital goods, machinery, equipment and foodstuffs (see Table 3). The quantitative expression of the tendency is well-illustrated by the figures shown in Table 2: the poor group has net import of manufacturing of over $17 \%$ and net export of primary goods of $10 \%$ of their GDP.

Some of these empirical facts have been documented in previous development literature. For example, Chari, Kehoe and McGrattan (1996) consider the ten fastest-growers and the ten slowest-growers and analyze their growth rates relative to the average during the 1960-1985 period. Further, Kongsamut, Rebelo and Xie (1997) focus on the effect of structural change on economic dynamics in 123 countries in the period 1970-1989 and find that an increase in per capita income leads to a decrease in the share of agricultural output and to an increase in the share of manufactured output in total GDP.

\section{The model}

In this section, we describe a two-sector economy and derive the equilibrium conditions. Subsequently, we consider two different variants of our economy, the autarkic and the open-economy.

\subsection{A two-sector economy}

Time is continuous, and the horizon is infinite. The consumer side of the economy consists of a continuum of infinitely-lived agents with their names on a closed interval $[0,1]$. As a result, average and aggregate quantities coincide in our model. The producer side of the economy is composed of two sectors: the primitive-goods sector and the sophisticated-goods sector, denoted by superscripts " $p$ " and " $s "$, respectively. 
An agent owns capital and natural resources and rents them to the production firms. Natural resources do not depreciate and stay constant over time. The capital stock in both primitive- and sophisticated-goods sectors depreciates at the rate $\delta \in(0,1]$. The agent spends the period's income on consumption and investment in both sectors. Only sophisticated goods can be used for consumption and investment. Hence, the agent faces the following constraints:

$$
\begin{gathered}
c_{t}+x_{t}^{p}+x_{t}^{s}=r_{t}^{p} k_{t}^{p}+r_{t}^{s} k_{t}^{s}+q_{t} N, \\
\dot{k_{t}^{p}}=x_{t}^{p}-\delta k_{t}^{p}, \\
\dot{k_{t}^{s}}=x_{t}^{s}-\delta k_{t}^{s},
\end{gathered}
$$

where $c_{t}$ is consumption; $x_{t}^{j}, k_{t}^{j}, r_{t}^{j}$, are, respectively, investment, capital and interest rate in a sector $j \in\{p, s\} ; N$ and $q_{t}$ denote natural resources and their price, respectively. Dots over $k_{t}^{p}$ and $k_{t}^{s}$ represent differentiation with respect to time.

The consumer has a period utility function of the Constant Relative Risk Aversion (CRRA) type and solves the following intertemporal utilitymaximization problem:

$$
\max _{c_{t}, k_{t}, k_{t}^{s}} \int_{0}^{\infty} e^{-\rho t}\left[\frac{c_{t}^{1-\sigma}-1}{1-\sigma}\right] d t
$$

subject to

$$
\begin{aligned}
& k_{t}=r_{t}^{p}\left(k_{t}-k_{t}^{s}\right)+r_{t}^{s} k_{t}^{s}+q_{t} N-\delta k_{t}-c_{t}, \\
& \left(k_{t}-k_{t}^{s}\right) \geq 0, \quad k_{t}^{s} \geq 0,
\end{aligned}
$$




$$
\lim _{t \rightarrow \infty}\left[k_{t}^{s} e^{-\int_{0}^{t} r_{v}^{s} d v}\right]=0
$$

where the initial condition $\left(k_{0}^{p}, k_{0}^{s}\right)$ is given. Here, $\rho>0$ is the discount rate; $\sigma>0$ is the utility function parameter; $k_{t}$ is the aggregate capital stock,

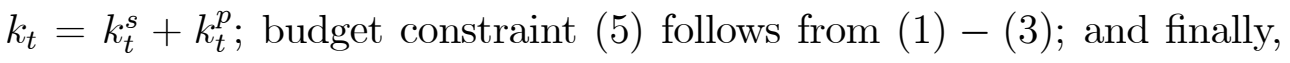
(7) is a no Ponzi game condition.

The primitive-goods sector consists of a representative firm that owns constant return-to-scale production technology, characterized by a Cobb-Douglas production function,

$$
y_{t}^{p}=B\left(k_{t}^{p}\right)^{\beta} N^{1-\beta},
$$

where $B>0$ and $\beta \in(0,1)$. The firm maximizes period-by-period profits by choosing the demand for capital and natural resources:

$$
\pi_{t}^{p}=\max _{k_{t}^{p}, N}\left\{p_{t} B\left(k_{t}^{p}\right)^{\beta} N^{1-\beta}-r_{t}^{p} k_{t}^{p}-q_{t} N\right\}
$$

where $p_{t}$ is the price of the primitive good (the price of the sophisticated good is normalized to one).

The sophisticated-goods sector is composed of a representative firm, whose production technology has constant returns to scale in private inputs and is subject to learning-by-doing and knowledge spillovers as in Romer (1986),

$$
y_{t}^{s}=\varphi_{t} A\left(k_{t}^{s}\right)^{\alpha} z_{t}^{1-\alpha}
$$

where $\varphi_{t}$ is the size of spillovers; $z_{t}$ is the amount of primitive goods produced; $A>0$; and $\alpha \in(0,1)$. The firm maximizes its period-by-period profit by taking $\varphi_{t}, r_{t}^{s}$ and $p_{t}$ as given:

$$
\pi_{t}^{s}=\max _{k_{t}^{s}, z_{t}}\left\{\varphi_{t} A\left(k_{t}^{s}\right)^{\alpha} z_{t}^{1-\alpha}-r_{t}^{s} k_{t}^{s}-p_{t} z_{t}\right\} .
$$

We assume that the size of spillovers $\varphi_{t}$ is determined by the sector's cumulative production experience, measured by its capital stock, i.e., $\varphi_{t} \equiv \varphi\left(k_{t}^{s}\right)$. 
If nobody in the economy produces sophisticated goods, the productivity of the sophisticated-goods sector is zero. When the sector develops, its productivity increases. We assume that the function $\varphi$ satisfies the following properties: $\varphi(0)=0, \lim _{k \rightarrow \infty} \varphi(k)=1, \varphi^{\prime}(k)>0, \lim _{k \rightarrow 0} \varphi^{\prime}(0)=\infty, \lim _{k \rightarrow \infty} \varphi^{\prime}(k)=0$. The assumption that learning-by-doing spillovers are limited by national borders (national spillovers) is also adopted in, e.g., Bardhan (1970), Krugman (1987), Lucas (1988). The models of international trade and endogenous growth that use the assumption of boundedness of learning-by-doing opportunities include, e.g., Stockey (1991), Young (1991). ${ }^{8}$

In our model, we interpret the production of primitive goods as traditional natural-resource-based production in real economies, such as agriculture, food and the primary-goods production. Thus, natural resources in our model are endowments of any inputs that are heavily used in naturalresource-based production (i.e., land, sea, fuel, ore). Likewise, we interpret the production of sophisticated goods in the model as modern industrial production in real economies, such as manufacturing and, in particular, high-tech industry.

\subsection{Equilibrium conditions}

Definition: $\square$ An equilibrium in the economy $(4)-(11)$ is definedlas a sequence of the individual quantities $\left\{c_{t}, k_{t}, k_{t}^{s}\right\}_{t=0}^{\infty}$, of the prices $\left\{r_{t}^{p}, r_{t}^{s}, p_{t}, q_{t}\right\}_{t=0}^{\infty}$ and of the production inputs $\left\{k_{t}^{p}, N, k_{t}^{s}, z_{t}\right\}_{t=0}^{\infty}$ such that given the prices

(i) $\left\{c_{t}, k_{t}, k_{t}^{s}\right\}_{t=0}^{\infty}$ solves the utility-maximization problem $(4)-(6)$;

(ii) $\left\{k_{t}^{p}, N\right\}_{t=0}^{\infty}$ solves the profit-maximization problem $\measuredangle(9)$;

(iii) $\left\{k_{t}^{s}, z_{t}\right\}_{t=0}^{\infty}$ solves the profit-maximization problem $(11)$;

(iv) the economy's resource constraint is satisfied. (The resource constraint depends on whether the economy is closed or open and will be speci-

\footnotetext{
${ }^{8}$ See Grossman and Helpman (2003) for a discussion of models of international trade with learning-by-doing.
} 
fied separately).

The Kuhn-Tucker conditions that describe the equilibrium can be written as follows:

$$
\begin{gathered}
k_{t}^{p}=0 \quad \text { and } \quad \frac{\dot{c_{t}}}{c_{t}}=\frac{1}{\sigma}\left[r_{t}^{s}-\delta-\rho\right], \\
k_{t}^{s}=0 \quad \text { and } \quad \frac{\dot{c_{t}}}{c_{t}}=\frac{1}{\sigma}\left[r_{t}^{p}-\delta-\rho\right], \\
r_{t}^{s}=r_{t}^{p}=r_{t} \quad \text { and } \quad \frac{\dot{c_{t}}}{c_{t}}=\frac{1}{\sigma}\left[r_{t}-\delta-\rho\right],
\end{gathered}
$$

which correspond to the two corner solutions and the interior solution, respectively. From $(9)$, the profit-maximization conditions of the primitive-goods firm are

$$
\begin{gathered}
r_{t}^{p}=p_{t} \beta B\left(k_{t}^{p}\right)^{\beta-1} N^{1-\beta}, \\
q_{t}=p_{t}(1-\beta) B\left(k_{t}^{p}\right)^{\beta} N^{-\beta},
\end{gathered}
$$

andfrom $(11)$, those of the sophisticated-goodls firmare

$$
\begin{gathered}
r_{t}^{s}=\varphi\left(k_{t}^{s}\right) \alpha A\left(k_{t}^{s}\right)^{\alpha-1} z_{t}^{1-\alpha}, \\
p_{t}=\varphi\left(k_{t}^{s}\right)(1-\alpha) A\left(k_{t}^{s}\right)^{\alpha} z_{t}^{-\alpha} .
\end{gathered}
$$

The equilibrium profits in both sectors are equal to zero, $\pi_{t}^{p}=0$ and $\pi_{t}^{s}=0$.

\subsection{An autarkic economy}

If an economy is in autarky, it cannot trade either primitive or sophisticated goods on international market. Thus, sophisticated goods in the autarkic 
economy can only be produced from its home-made primitive goods. According tol (8), (10), we have

$$
z_{t}=y_{t}^{p} \quad \text { and } \quad y_{t}^{s}=\varphi\left(k_{t}^{s}\right) A\left(k_{t}^{s}\right)^{\alpha}\left[B\left(k_{t}^{p}\right)^{\beta} N^{1-\beta}\right]^{1-\alpha} .
$$

Since agents can consume only sophisticated goods, and these cannot be bought on the international market, the sophisticated-goods production is non-zero, $k_{t}^{s} \neq 0$. Furthermore, since the production of sophisticated goods requires the use of primitive goods as an input, the primitive-goods production is also non-zero, $k_{t}^{p} \neq 0$. Thus, the optimal allocation is interior in autarky, and both sectors are developed from the beginning. Substituting $\sqsubset(15)$ - (19) into (5), we bbtain the resource constraint @f the autarkic economy

$$
\dot{k_{t}}=\varphi\left(k_{t}^{s}\right) A\left(k_{t}^{s}\right)^{\alpha}\left[B\left(k_{t}^{p}\right)^{\beta} N^{1-\beta}\right]^{1-\alpha}-\delta k_{t}-c_{t} .
$$

According to (14), in the interior equilibrium, the interest rate on capital in both sectors is equal, $r_{t}^{p}=r_{t}^{s}=r_{t}$, i.e.,

$$
\begin{gathered}
\varphi\left(k_{t}^{s}\right) A(1-\alpha)\left(k_{t}^{s}\right)^{\alpha}\left[B\left(k_{t}-k_{t}^{s}\right)^{\beta} N^{1-\beta}\right]^{-\alpha} B \beta\left(k_{t}-k_{t}^{s}\right)^{\beta-1} N^{1-\beta}= \\
\varphi\left(k_{t}^{s}\right) A \alpha\left(k_{t}^{s}\right)^{\alpha-1}\left[B\left(k_{t}-k_{t}^{s}\right)^{\beta} N^{1-\beta}\right]^{1-\alpha} .
\end{gathered}
$$

Condition $\left[(21)\right.$ yields the following relations [between $\left\lceil k_{t}^{p}, k_{t}^{s}\right.$ and $k_{t}$

$$
k_{t}^{p}=\frac{\beta-\beta \alpha}{\beta-\beta \alpha+\alpha} k_{t} \quad \text { and } \quad k_{t}^{s}=\frac{\alpha}{\beta-\beta \alpha+\alpha} k_{t} .
$$

That is, both types of capital, $k_{t}^{p}$ and $k_{t}^{s}$, are in fixed proportions to the total capital, $k_{t}$. With this result, we can write the interest rate as

$$
r_{t} \equiv r\left(k_{t}\right)=\theta \varphi\left(\frac{\alpha}{\beta-\beta \alpha+\alpha} k_{t}\right) k_{t}^{-(1-\beta)(1-\alpha)},
$$

where

$$
\theta \equiv \beta(1-\alpha) B^{1-\alpha} A N^{(1-\beta)(1-\alpha)} \frac{\alpha^{\alpha}[\beta(1-\alpha)]^{\beta-\beta \alpha-1}}{(\beta-\beta \alpha+\alpha)^{-(1-\beta)(1-\alpha)}}
$$


By substituting the equilibrium interest rate(23) in the Euler equation (14) and the formulas for $k_{t}^{p}$ and $k_{t}^{s}$ from $\square(22)$ into $\square$ budget $\|$ constraint $\square(5)$, we obtain

$$
\begin{gathered}
\dot{c}_{t}=\frac{c_{t}}{\sigma}\left[\theta \varphi\left(\frac{\alpha}{\beta-\beta \alpha+\alpha} k_{t}\right) k_{t}^{-(1-\beta)(1-\alpha)}-\delta-\rho\right], \\
\dot{k_{t}}=\frac{\theta}{\beta-\beta \alpha+\alpha} \varphi\left(\frac{\alpha}{\beta-\beta \alpha+\alpha} k_{t}\right) k_{t}^{\alpha+\beta(1-\alpha)}-\delta k_{t}-c_{t} .
\end{gathered}
$$

A steady state is defined as a situation in which all the model's variables have constant values. In the steady state, we have $\dot{c}_{t}=0$ and $\dot{k}_{t}=0$, so that conditions $(25)$ and $(26)$ imply, respectively,

$$
\begin{gathered}
\varphi\left(\frac{\alpha}{\beta-\beta \alpha+\alpha} k_{t}\right) k_{t}^{-(1-\beta)(1-\alpha)}=\frac{\rho+\delta}{\theta}, \\
c_{t}=\frac{\theta}{\beta-\beta \alpha+\alpha} \varphi\left(\frac{\alpha}{\beta-\beta \alpha+\alpha} k_{t}\right) k_{t}^{\alpha+\beta(1-\alpha)}-\delta k_{t} .
\end{gathered}
$$

Duetothe presence of externalities, equation (27) can havemultiplelsolutions and thus, our economy can have multiple steady states. To rule out the multiplicity of steady states, we assume that the marginal productivity of capital (interest rate), $r\left(k_{t}\right)$, definedin (23) has the same propertiestas one under the standard neoclassical production function, i.e.,

$$
r\left(k_{t}\right)>0, \quad r^{\prime}\left(k_{t}\right)<0, \quad \lim _{k_{t} \rightarrow 0} r\left(k_{t}\right)=\infty, \quad \lim _{k_{t} \rightarrow \infty} r\left(k_{t}\right)=0 .
$$

(In the standard case, the properties of $r\left(k_{t}\right)$ पlisted $i n \square(29)$ result $\|$ from the assumptions that the production function is strictly increasing, strictly concave and satisfies the Inada conditions). In fact, the assumptions in (29) not only guarantee the uniqueness of the steady state but also insure that the dynamicusystem $(25),((26) \|$ is $\|$ saddlelpath $/$ stable!

We shall summarize our results with the following proposition: 
Proposition 1 (a) If an equilibrium exists in the autarkic economy, then, it is interior, i.e., both the primitive- and sophisticated-goods sectors are developed from the beginning.

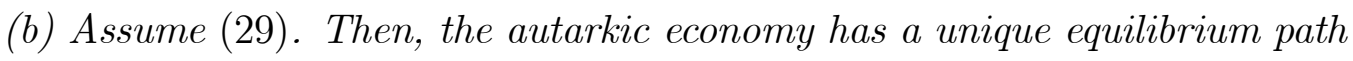
which asymptotically converges to a steady state.

We describe the steady state of the autarkic economy in a subsequent section, as it coincides with one of the steady states of the open economy.

\subsection{An open economy}

If an economy is open, it need not consume all of the domestically produced goods but can trade some of them on the international market. We shall assume that the domestic country is small, so that its trade has no effect on the world price, and that the world price is constant, $p_{t}=p$ for all $t$. Furthermore, we shall assume that capital is immobile, so that there is no international borrowing and lending. By combining (15)-(19)/and(5), we obtain the resource constraint of the open economy

$$
\dot{k_{t}}=\varphi\left(k_{t}^{s}\right) A\left(k_{t}^{s}\right)^{\alpha} z_{t}^{1-\alpha}+p\left(B\left(k_{t}^{p}\right)^{\beta} N^{1-\beta}-z_{t}\right)-\delta k_{t}-c_{t} .
$$

We can establish the country's international specialization by looking


production of sophisticated goods,

$$
z_{t}=\left(p^{-1} \varphi\left(k_{t}^{s}\right)(1-\alpha) A\right)^{1 / \alpha} k_{t}^{s} \quad \text { and } \quad z_{t} \lesseqgtr y_{t}^{p} .
$$

If $z_{t}<y_{t}^{p}$, then the country produces mostly primitive goods exchanging primitive goods in the amount $\left(y_{t}^{p}-z_{t}\right)$ for sophisticated goods. If, on opposite, $z_{t}>y_{t}^{p}$, then the country produces mostly sophisticated goods. Finally, if $z_{t}=y_{t}^{p}$, the country does not trade goods on the international market. 
According to the Kuhn-Tucker/conditions (12)-(14), the countrylchooses from three different international specializations, namely, to produce either only sophisticated goods, or only primitive goods or both kinds of goods, with the aggregate capital stock being distributed to satisfy $r^{p}\left(k_{t}^{p}\right)=r^{s}\left(k_{t}^{s}\right)$, where

$$
\begin{gathered}
r^{p}\left(k_{t}^{p}\right) \equiv p \beta B\left(k_{t}^{p}\right)^{\beta-1} N^{1-\beta}, \\
r^{s}\left(k_{t}^{s}\right) \equiv \varphi\left(k_{t}^{s}\right)^{1 / \alpha} \alpha A^{1 / \alpha}\left(p^{-1}(1-\alpha)\right)^{(1-\alpha) / \alpha} .
\end{gathered}
$$

Condition $\measuredangle(33)$ follows after substituting $[(31)$ in $\measuredangle(17)$.

Note that the corner solution, to produce only sophisticated goods, is not an equilibrium. Indeed, if all capital is concentrated in the sophisticatedgoods sector, we have $r^{s}\left(k_{t}\right)<\infty$ and $\lim _{k_{t}^{p} \rightarrow 0} r^{p}\left(k_{t}^{p}\right)=\infty$, so that a pricetaking agent can increase the period's capital income by re-investing from the sophisticated- to primitive-goods sector, which means that the strategy $k_{t}^{p}=0$ is not utility-maximizing. In contrast, the other corner solution, to produce only primitive goods, is an equilibrium. To see this, note that if all capital is invested in the primitive-goods sector, we have $r^{s}(0)=0$, so that a unilateral deviation of a price-taking agent from the equilibrium strategy $k_{t}^{s}=0$ reduces the agent's period capital income. Finally, note that any interior solution is an equilibrium because we have $r^{p}\left(k_{t}^{p}\right)=r^{s}\left(k_{t}^{s}\right)$, and thus, any distribution of capital between the sectors is consistent with the utility-maximization of a price-taking agent. Hence, our economy has multiple equilibria, which is a result of increasing returns to scale at the aggregate level.

At low levels of economic development, an interior solution is not feasible since the rate of return on capital in the primitive-goods sector is higher than the one in the sophisticated-goods sector, independently of how the total capital is split between the sectors (in the limit, we have $\lim _{k_{t} \rightarrow 0} r^{p}\left(k_{t}^{p}\right)=\infty$ 
and $\lim _{k_{t} \rightarrow 0} r^{s}\left(k_{t}-k_{t}^{p}\right)=0$ for all $\left.k_{t}^{p} \in\left(0, k_{t}\right]\right)$. Hence, a low-capital country produces only primitive goods.

When the country accumulates a sufficiently large capital stock, it may switch to the interior solution (14). Letus establish a minimal tvalue for $\|$ aggregate capital stock, $\bar{k}$, for which the interior solution is feasible. The equality of the sectorial interest rates, together with (32) and (33), determines the optimal distribution of aggregate capital between the sectors, according to

$$
\varphi\left(k_{t}-k_{t}^{p}\right)^{1 / \alpha}\left(k_{t}^{p}\right)^{1-\beta}=\frac{p \beta B N^{1-\beta}}{\alpha A^{1 / \alpha}\left[p^{-1}(1-\alpha)\right]^{(1-\alpha) / \alpha}} \equiv \xi .
$$

We define $\Im\left(k_{t}\right)$ as the maximum value that the left side of (34) can achieve for a given value of $k_{t}$, i.e.,

$$
\Im\left(k_{t}\right) \equiv \max _{k_{t}^{p}}\left\{\varphi\left(k_{t}-k_{t}^{p}\right)^{1 / \alpha}\left(k_{t}^{p}\right)^{1-\beta}\right\}
$$

Given that $\Im$ is a strictly increasing, continuous function with $\Im(0)=0$ and that $\lim _{k_{t} \rightarrow \infty} \Im\left(k_{t}\right)=\infty$, we conclude that there exists a unique threshold value for the aggregate capital stock $\bar{k}$ satisfying $\Im(\bar{k})=\xi$. As the equilibrium is interior by assumption, we can characterize the threshold value by means of theffirst-order $\|$ condition 0 f $[(35)$,

$$
\frac{\varphi^{\prime}\left(k_{t}-k_{t}^{p}\right) k_{t}^{p}}{\varphi\left(k_{t}-k_{t}^{p}\right)}=(1-\beta) \alpha .
$$

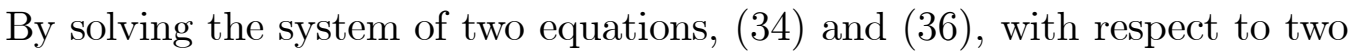
unknowns, $k_{t}$ and $k_{t}^{p}$, we obtain the threshold aggregate capital stock, $\bar{k}$, and the optimal size of the primitive-goods sector, $\bar{k}^{p}$. The solution is situated in the point where $r^{p}\left(k_{t}^{p}\right)$ and $r^{s}\left(k_{t}-k_{t}^{p}\right)$ are tangent, which is illustrated in Figure 4.

Finally, when the country develops beyond the threshold level, $k_{t}>\bar{k}$, there $\lceil$ are two $₫$ different interior $\|$ solutions to tequation $\square(34)$. Thus, at high 
levels of development, the country has to choose among three alternatives, namely, one corner solution and two interior solutions (see Figure 4).

Due to the presence of multiple solutions, our open economy has indeterminacy of equilibrium, in the sense that it can switch between the three solutions in an arbitrary manner at any point of time. We must emphasize, however, that switching among solutions is not a fundamental property of our model, but rather, a result of our simplifying assumption that capital can be costlessly and instantaneously transferred from one sector to another. We would not have switching between solutions in a more realistic environment, where the re-allocation of capital between sectors is costly. We therefore restrict our attention to a case in which the economy sticks to the same solution until a coordinating agent, e.g., government, enforces a switch to another solution. We refer to the equilibrium dynamic paths corresponding to the corner and two interior solutions as Equilibria I, II, III.

In particular, we are interested in the case where the price $p$ in the open economy is equal to the steady state price in the autarkic economy considered in Section 4. This assumption allows us to compare the steady states of the autarkic and the open economies. A steady state value of a variable $x$ in the autarkic economy is denoted by $x_{A \text {. }}^{*}$ By expressing $z_{t}$ from $(17)$, substituting

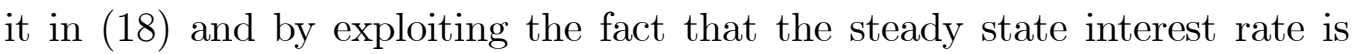
equal to $(\delta+\rho)$, we obtain the steady state price of the autarkic economy

$$
p_{A}^{*}=\left[\frac{\varphi\left(k_{A}^{s, *}\right) A \alpha^{\alpha}}{(\rho+\delta)^{\alpha}}\right]^{1 /(1-\alpha)}(1-\alpha) .
$$

In the open economy, steady state values of a variable $x$ in Equilibria I, II, III are denoted by $x_{I}^{*}, x_{I I}^{*}, x_{I I I}^{*}$, respectively. We describe the three equilibria in the open economy below.

Equilibrium I (Poverty-trap equilibrium). The country produces only primitive goods. As such, its dynamic behavior is described by the budget

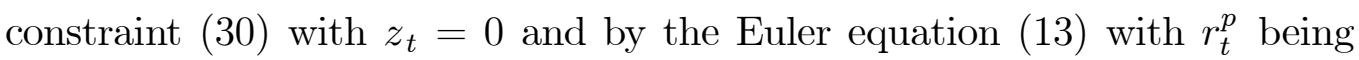




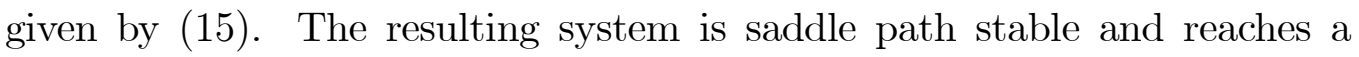
steady state with a zero growth rate. Thus, we have

$$
k_{I}^{p, *}=\left(\frac{\delta+\rho}{p B \beta}\right)^{1 /(\beta-1)} N \quad \text { and } \quad k_{I}^{s, *}=0 .
$$

We refer to this equilibrium as the "poverty-trap" because a low developed country, that only produces primitive goods, might be unable to accumulate the threshold capital stock, $\bar{k}$, necessary for opening the sophisticated-goods sector, thus, remaining poor forever.

Equilibrium II (Autarky-like equilibrium). The country produces both kinds of goods; it shrinks its sophisticated-goods sector and expands its primitive-goods sector in its process of economic development. The dynamics of such an economy are described by the budget constraint, obtained after substituting $\square(31)$ into $\square(30)$, and $\square$ by the $\angle$ Euler $\square$ equation $\square(14)$, with $r_{t}^{p}$ and

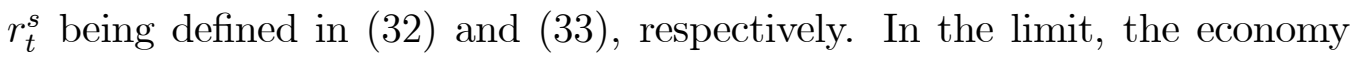
reaches a steady state with the same size of the primitive-goods sector as in Equilibrium I, $k_{I I}^{p, *}=k_{I}^{p, *}$, i.e.,

$$
k_{I I}^{p, *}=\left(\frac{\delta+\rho}{p B \beta}\right)^{1 /(\beta-1)} N \quad \text { and } \quad k_{I I}^{s, *}=\varphi^{-1}\left[\xi\left(k_{I I}^{p, *}\right)^{\beta-1}\right]^{\alpha} .
$$

where the steady-state size of the sophisticated-goods sector is determined by the equality of theinterest rates in/(32)/and((33). WWecall this equilibrium "autarky-like", because if $p=p_{A}^{*}$, the open economy has the same steady state allocation as the autarkic economy does. ${ }^{9}$ Indeed, given that the steady state interest ratein both economies is equal to $[\delta \boxminus \rho)$, according to (15), we obtain that both economies have the same capital stock in the primitivegoods sector. Furthermore, by substituting $\xi$ and $p_{A}^{*}$ from $\square(34) \sqsubset$ and $\square(37)$,

\footnotetext{
${ }^{9}$ In spite of having the same steady state, the autarkic economy and the open economy in Equilibrium II have different equilibrium dynamics. In particular, in the autarkic economy, the price changes with time, whereas in the open economy, it is constant.
} 
respectively, into $k_{I I}^{s, *}$ in $\measuredangle(39)$, «we show that bothleconomies have thelsame capital stock in the sophisticated-goods sector.

Equilibrium III (Growth-miracle equilibrium). This is the interior equilibrium in which the primitive-goods sector is shrinking and the sophisticatedgoods sector is expanding during the development process. The budget constraint and the Euler equation here coincide with those we had in Equilibrium II. Asymptotically, the model converges to the standard $A K$-model where " $A$ " is defined by

$$
\lim _{k_{t} \rightarrow \infty} r^{s}\left(k_{t}^{s}\right)=\alpha A^{1 / \alpha}\left[p^{-1}(1-\alpha)\right]^{(1-\alpha) / \alpha} \equiv \mathcal{A} .
$$

We assume that the growth rate of consumption, following from the Euler equation $(14)$, is positive, $\gamma_{I I I}^{*} \equiv\left(\frac{\dot{c}_{t}}{c_{t}}\right)^{*}=\frac{1}{\sigma}[\mathcal{A}-\delta-\rho]>0$. (This is always the case under $p=p_{A \sqsubset \operatorname{as}}^{*}(40) \sqsubset$ yields $\left.\square \mathcal{A} \square \frac{\delta+\rho}{\varphi\left(k_{A}^{*, s}\right)}>\delta+\rho\right)$. Therefore, the economy asymptotically converges to a balanced growth path, where, accord-

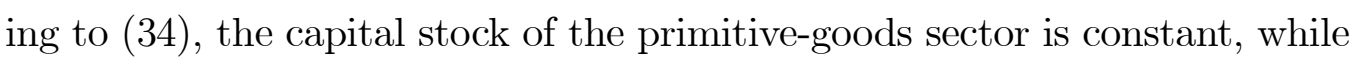
that of the sophisticated-goods sector grows at the same rate as consumption does,

$$
k_{I I I}^{p, *}=\xi^{1 /(1-\beta)} \quad \text { and } \quad\left(\frac{\dot{k_{t}^{s}}}{k_{t}^{s}}\right)^{*}=\gamma_{I I I}^{*} .
$$

With the term "growth-miracle" that we employ for this equilibrium, we emphasize that it is possible to have eternal growth in the open economy, in contrast to the autarkic economy, where long-run growth is not feasible.

The results obtained for the open economy are summarized below:

Proposition 2 Let $\bar{k}$ be the threshold capital stock of the open economy defined $b y[(34),(36)$.

(a) Under $k_{t}<\bar{k}$, the economy produces only primitive goods.

(b) Under $k_{t}=\bar{k}$, the sophisticated-goods sector can be opened. If so, 
$\bar{k}^{s}=\bar{k}-\bar{k}^{p}$ is transferred to the sophisticated-goods sector and $\bar{k}^{p}$ is left in the primitive-goods sector, where $\bar{k} \square$ is $\square$ determined $\square y \llbracket(36)$.

(c) Under $k_{t}>\bar{k}$, there are three different equilibria.

Eq. I. The economy only has a primitive-goods sector and it asymptotically converges to the steady statel(38).

Eq. II. The economy expands the primitive-goods sector and diminishes the sophisticated-goods sector; it asymptotically converges to the steady state (39).

Eq. III. The economy expands the sophisticated-goods and reduces the primitive-

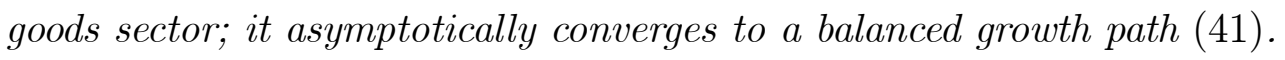

Equilibria I, II, II can be ranked by welfare. For any given initial capital $k_{0} \geq \bar{k}$, we have that the interest rate in Equilibrium III is larger than the one in Equilibrium II, which in turn, is larger than the one in Equilibrium I, for all $t$. According to the Euler equation, a larger interest rate implies a larger consumption growth rate. Hence, Equilibrium III dominates Equilibrium II, which in turn, dominates Equilibrium I in the level of utility. ${ }^{10}$

\section{Accounting for the stylized facts}

In this section, we argue that our model is consistent with the stylized facts documented in Section 2. We shall start by presenting the view of the postwar worldwide economic development, as our model suggests. Following Atkeson and Kehoe (2000), we assume that different countries begin their economic development at different dates. To be specific, we consider the world as being

\footnotetext{
${ }^{10}$ As far the issue of stability is concerned, all our equilibria are stable to deviations of one agent from the equilibrium strategy, as such deviations have no effect on prices. If we consider deviations that affect prices, Equilibrium II will be unstable because of the Marshallian tatonnement argument (see Matsuyama, 1991). One can make Equilibrium II stable in the latter sense by introducing adjustment costs as in Graham and Temple (2003).
} 
composed of two groups of countries: i.e., the early-blooming group, consisting of both autarkic and open economies that have reached the autarky-like steady state (39) and the late-blooming group, consisting of -open/economies that have just begin to develop. We assume that the late-blooming group is small, relative to the early-blooming group, so that the choices of the latebloomers do not affect the world price, which is equal to the steady state pricelin the early-blobming countries (37).

For the world economy, the implications of our model are the same as for the autarkic economy in Section 4. In particular, we have that long-run growth is impossible at the world level. Indeed, there are decreasing returns to primitive-goods production because the available amount of one of the production factors, natural resources, is fixed. Given that primitive goods are used as inputs for producing sophisticated goods, in equilibrium, we also have (asymptotically) decreasing returns to sophisticated-goods production, as formulal (19) shows. $\square$ Hence, $\llbracket$ nearly all the world economies end $\square p$ in $\lceil a n$ autarky-like steady state, as our early-blooming group does.

According our model, a small open economy does not need to share a common destiny: it can do either worse than, as good as, or better than the world in general does, depending on the sort of equilibrium it has. Below, we argue that the three groups of countries distinguished in Section 2, namely, the poor, rich and fast-growing groups, can be viewed as being situated in Equilibria I, II, and III, respectively.

First, as follows from our model, being a small open economy is a curse if the poverty-trap equilibrium (Equilibrium I) is chosen. Such an economy produces only primitive goods and exchanges them for sophisticated goods on the international market, and it converges to the poverty-trap steady state with a lower consumption (welfare) than the world's average. The features of ten late-blooming African countries from our poor group seem to fit the above description. 
Secondly, our model predicts that a small open economy can reach the world's average if it mimics the behavior of the autarkic economy by choosing Equilibrium II. Such an economy produces both primitive and sophisticated commodities, and it converges to the autarky-like steady state with no trade on the international market. ${ }^{11}$ The above description seems to suit the rich early-blooming countries in the data. Note that our rich group includes both large developed economies (like the U.S., Japan, Canada) and small developed economies (like Luxembourg, Iceland, Norway, Denmark). In fact, our model is consistent with this empirical observation: one can view large developed economies as being in autarky, and one can view small developed economies as open economies being in Equilibrium II.

Finally, according to our model, being a small open economy becomes a blessing if it produces mostly sophisticated goods (Equilibrium III), and exchanges them for primitive goods on the international market. Such an economy has positive long-run growth, i.e., it becomes a growth-miracle. Eternal growth is possible for a small open economy because it can buy primitive goods used in the production of sophisticated goods at a constant world price $p$, and hence, has constant returns to scale in the production of sophisticated goods. A distinctive property of Equilibrium III is that the country's share of primitive-goods production decreases and that of its sophisticated-goods production increases over time. The above features are indeed characteristic of the fast-growing countries in the data. ${ }^{12}$

\footnotetext{
${ }^{11}$ To be precise, in the autarky-like steady state, there is no trade of primitive goods for sophisticated goods or vise versa. Note that exchange of one primitive (sophisticated) good for another primitive (sophisticated) good is not considered to be "trade" in our model, as we do not have different primitive (sophisticated) goods. Hence, our model is consistent with the observation that the developed countries are both importers and exporters of sophisticated goods (see Table 3) as long as their net export (import) is zero.

${ }^{12}$ In addition, the prediction of our model, that the fast-growing countries would have increasing returns to scale in the early stages of development and constant returns to scale in recent years, is consistent with the empirical evidence on the East Asian economies, documented by Park and Ryu (2003). Furthermore, this study finds that the East Asian
} 


\section{Making a miracle}

According to our theory, different countries show distinct types of economic performance because they have selected different sorts of equilibria. In this section, we analyze three factors that are important for the choice of a given type of equilibrium, specifically: their endowment of capital, their endowment of natural resources and their government's economic policy. We argue that these factors are indeed relevant in explaining the different development experiences of actual economies.

\subsection{Escaping the poverty trap}

In the absence of externalities, $\varphi(k)=1$ for all $k$, a small open economy has an $A K$-type of technology for producing sophisticated goods. As there are decreasing returns to the primitive-goods production, such an economy will open the sophisticated-goods sector once the marginal productivity of capital in the primitive-goods sector reaches the constant productivity of the sophisticated-goods sector. Starting from this point, we have a constant size of the primitive-goods sector and an increasing size of the sophisticated-goods sector, so that asymptotically, we obtain an $A K$ model. ${ }^{13}$

With externalities, it might be that the economy never accumulates sufficient capital to open a sophisticated-goods sector. Indeed, it could be that the steady state capital stock of the economy producing only primitive goods, $k_{I}^{p, *}$, is lower than the required threshold capital, $\bar{k}$, which was shown to be necessary for launching of a sophisticated-goods sector. If this is so, the economy is caught up in the poverty trap forever, producing only primitive goods. This is presumably what happens to the countries in our poor group.

economic growth was due to the accumulation of physical capital, and not to technical progress, which is also in agreement with our model.

${ }^{13}$ As was mentioned in the introduction, this implication is parallel to the one obtained in Hansen and Prescott (2000). 
To escape the poverty trap, a developing country should adopt different policies to help it reach the threshold level $\bar{k}$. One possibility would be to ask for international aid, and/or, to attract foreign investment. Another possibility would be to reduce the threshold level $\bar{k}$ by employing an appropriate fiscal policy. For example, the government can tax primitive-goods producers and subsidize sophisticated-goods producers: the former policy pushes down

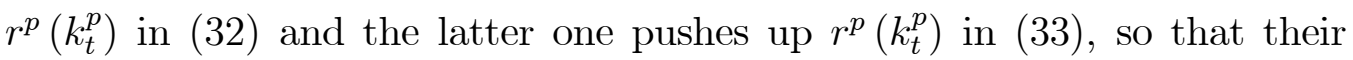
intersection, $\bar{k}$, is reduced. ${ }^{14}$

There are examples of developing countries that have benefited from such policies. Foreign aid gave a boost to the development of the two growthmiracles of South Korea and Thailand. The discriminatory tax-subsidy schemes were crucial for promoting export-oriented industries in South Korea and Japan. However, there are also numerous examples of developing countries (especially, in Latin America) that received large foreign help and did very poorly afterwards. Our model suggests the following explanation to this phenomenon: in order to become a growth miracle, a country should not only accumulate the threshold amount of capital but should also coordinate on the right equilibrium. We discuss this issue in Section 5.4.

\section{$5.2 \quad$ Natural resources}

We shall now analyze the role of natural resources in economic development. From $\square(34)$ and $(36)$ and from $(38)$, we obtain, respectively:

$$
\frac{d \log \bar{k}}{d \log N}=\frac{\bar{k}^{p}}{\bar{k}}<1 \quad \text { and } \quad \frac{d \log k_{I}^{p, *}}{d \log N}=1 .
$$

\footnotetext{
${ }^{14}$ An economy ruled by a benevolent central planner (dictator) has a greater chance of escaping from the poverty trap than a market economy does. First, the planner internalizes externalities and, thus, faces a lower threshold $\bar{k}$, and secondly, the planner can adopt development strategies that are not feasible in a market economy, such as developing its sophisticated-goods sector when it is still unprofitable or to go beyond the (poverty-trap) steady state of the primitive-goods sector.
} 


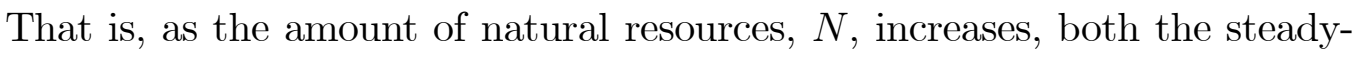

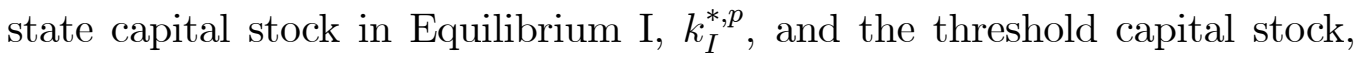

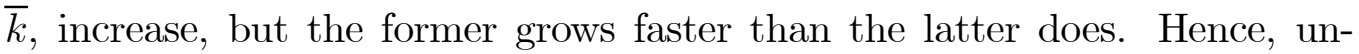
$\operatorname{der} \|$ a sufficiently large $\square N$, we have $k_{I}^{*, p}>\bar{k}, \varpi$ which implies that a country with abundant natural resources is ablelto accumulate enough capital in the primitive-goods sector tolaunch the Sophisticated-goods sector. The converse is also true: a country with scarcenatural resources is nnever abletoreach the threshold necessary for launching a sophisticated-goods sector. Thus, in the absence of international aid, only countries that are rich in natural resources have any chance of developing.

If international aid is available but limited, abundant natural resources could $\square$ become $\square$ an $\square$ obstacle $\_$for $\square$ growth. $\square$ Indeed, $\square$ as $\square$ follows $\square$ from $\square(42)$, the threshold capital stock, $\bar{k}$, for countries with abundant natural resources is larger than that for countries with scarce natural resources. In particular, in the limit, we have $\lim _{N \rightarrow 0} \bar{k} \rightarrow 0$. Therefore, a country with few natural resources can reach its threshold level $\bar{k}$ with little international aid, as opposed to a country with great natural resources, which needs a relatively large international aid to do so.

Consequently, the effect of natural resources on growth, in our model, is dual: on one hand, the richness in natural resources increases the production possibilities of the country, but on the other hand, it incentivates the production of primitive goods excessively and distracts the economic agents from more sophisticated and more efficient production alternatives. These predictions of our model are to much extent similar to those of Matsuyama's (1992) model if variations in the agricultural productivity in the latter model are interpreted as variations in the endowment of natural resources in our model. ${ }^{15}$

\footnotetext{
${ }^{15}$ The dual role of natural resources in economic development is also emphasized in

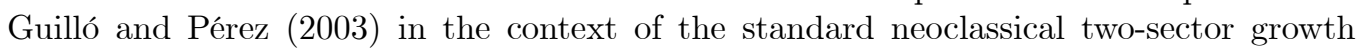


The model's implication about the dual role of natural resources in economic growth appears to be in agreement with the data. ${ }^{16}$ The fast-growing countries are generally short of natural resources. This is particularly true for the Four East Asian dragons (Singapore, South Korea, Hong Kong, Taiwan) and Malta. The most outstanding of them, Singapore, started with greater adversities than the other three dragons, and is now the most developed country among them. Malta has no rivers, no minerals, no domestic energy sources and poor soil. As reported in Gylfason and Zoega (2001), in Japan, Thailand, China, Malaysia, Indonesia, natural resources make up $0.8 \%, 6.5 \%, 7.2 \%, 8.6 \%, 12.4 \%$ of national wealth, respectively, which also points to the fact that the fast-growers are resource-poor. (For the other fast-growers, the corresponding reliable data are not available). The above countries, however, managed to overcome their resource constraints by developing large export-oriented manufacturing sectors. In contrast, the poor slow-growing countries identified earlier are very rich in terms of natural resources: in all these countries, natural resources represent more than $15 \%$ of their national wealth (an exception is Malawi, where this figure is slightly lower); remarkably, in Sierra Leone, Chad, Madagascar and Niger, natural resources represent $28 \%, 37 \%, 42 \%$ and $54 \%$ of national wealth, respectively; see Gylfason and Zoega (2001). These resource-rich countries export raw materials and agricultural products in exchange for more sophisticated manufacturing goods, so that their own production of sophisticated goods remains underdeveloped. At the same time, the example of two "African growth miracles", Oman and Botswana, demonstrates that abundant natural resources can be a boost rather than an obstacle to growth. (Oman and Botswana are exceptionally rich in fuel and diamonds, respectively). The success of

model with fixed sector-specific inputs.

${ }^{16}$ The empirical literature that studies the relationship between the richness in natural resources and economic growth includes, e.g., Sachs and Warner (1995), Gylfason, Herbertsson and Zoega (1999), Gylfason and Zoega (2001). 
these two countries is explained by their strategy of investing income from the exportation of natural resources to initiate industrialization.

\subsection{The coordinating role of government}

The key implication of our model is that the economic performance of a small open economy depends crucially on which type of equilibrium it selects. As we argued in Sections 5.2 and 5.3, some countries can converge more easily to a good equilibrium than others, because of their larger capital endowment or their greater wealth in natural resources. However, even the most favorable initial conditions do not guarantee that a country will become a growth miracle. Only those countries that manage to coordinate on the growthmiracle equilibrium will do so.

The government is a natural candidate for performing the coordinating role. The importance of the government's policy on economic development can be seen clearly by looking at the experience of the fast-growing countries. In Singapore, the basic industrialization program was initiated and managed by the government; in particular, the government consulted a UN development expert, who recommended the rapid build up of the manufacturing sector. In South Korea, with the military takeover in 1961, economic policy changed from reconstruction and import substitution to the aggressive promotion of exportation. The economic expansion of Malaysia was urged on by the government in the late 1960s, by initiating its import-substitution industrialization program in heavy industry. The Japanese government played an important coordinating role in overcoming the market failures that inhibited the economy's structural transformation. ${ }^{17}$ Malta has based its economic

\footnotetext{
${ }^{17}$ Rodrik (1996, p.19) also emphasizes the importance of the governments' coordination for successful economic performance of the fast-growing East Asian countries: "... the governments of Japan, South Korea, and Taiwan played an active role in coordinating, subsidizing, and guiding private investment decisions. This active role was implemented through the governments' control over the allocation of credit, through tax and other
} 
growth on the promotion of the exportation of manufactured goods (as well as tourism). In the case of Botswana, the source of its growth was mineral wealth, which the Botswana's government was able to transform into long-term growth by channelling funds into the development of manufacturing. Another fast-growing country with rich natural resources, Oman, has had a similar experience: income generated from the exportation of natural resources was used for the development of physical and social infrastructure.

A crucial role of government in the process of economic development can be also appreciated by comparing the experience of Botswana with that of Sierra Leone, another African country that exports diamonds. As was discussed above, Botswana now has a high-performance economy because its government was able to take advantage of its wealth in diamonds by implementing the adequate economic policy. In contrast, Sierra Leone is one of the poorest countries in the world, mainly because its government was unable to stop a domestic conflict that originated over its rich diamond supply and which destroyed the country's infrastructure and social institutions.

China is another example of a government that played a key role in initiating and promoting economic development. The Chinese government implemented a gradual transition from a command economy to a market economy, generally maintaining its old institutions and slowly reshaping them to meet the needs of its market economy. In particular, as a first step, the government introduced market forces in agriculture and only after agriculture had been sufficiently developed, began the necessary reforms in industry. In fact, this development strategy is precisely what leads to a growth-miracle equilibrium in our model: It, first, accumulates the threshold amount of capital in the primitive-goods sector and then, it switches to a growth-miracle equilibrium by shifting the resources to the sophisticated-goods sector.

incentives, administrative guidance, and when all else failed, public enterprises". 


\section{Conclusion}

This paper develops a two-sector model of international trade and economic growth with the aim of explaining postwar international growth experiences. The open-economy variant of our model has multiple equilibria because one of the production sectors has increasing returns to scale. Depending on the equilibrium chosen, a small open economy can do either worse, as good as, or better than the world average. These model's implications are consistent with the tendencies that we observe in the data since 1950s, namely, that the initially rich nations have remained rich, most of the poor nations have remained poor and some of the poor nations have become growth miracles. We emphasize the importance of government interventions in a country's successful economic performance by arguing that an appropriate policy can help the economy coordinate on a superior equilibrium.

As a final comment, we should point out one important limitation to our analysis. We take a rather simplified view of the world economy by assuming that it is composed of developed autarkic economies which determine world prices and of small developing open economies which have no effect on world prices. In reality, world prices arise as an outcome of the interactions among all countries, and, in particular, are affected by the actions of developing countries. This fact is potentially important for the properties of equilibrium in the world economy. One implication of our model that will not survive the introduction of fully endogenous price determination is that a small open economy can grow forever. Indeed, eternal growth is possible for a small open economy because it faces constant prices. However, as such an economy grows larger, it starts affecting world prices, so that its growth must slow down. (Presumably, this effect accounts for the slow-down in the Japanese growth rate during the last decade). To address this and other similar issues, one has to set up a multi-country general equilibrium model of international trade 
and economic growth. A characterization of equilibrium in such a model is, in general, a difficult task. One possible way of proceeding in this direction would be to employ the aggregation theory, see, e.g., Caselli and Ventura (2000), and Maliar and Maliar (2003).

\section{References}

[1] Atkeson, A. and P. Kehoe, 2000, Paths of development for early- and late-bloomers in a dynamic Heckscher-Ohlin model, Federal Reserve Bank of Minneapolis, Research Department Staff Report 256.

[2] Bardhan, P., 1970, Economic growth, development and foreign trade. (New York: John Wiley and Sons).

[3] Caselli, F. and J. Ventura, 2000, A representative consumer theory of distribution, American Economic Review, 90, 909-926.

[4] Chari, V., P. Kehoe and E. McGrattan, 1996, The poverty of nations: a quantitative exploration, NBER Working Paper 5414.

[5] Choi, J. and E. Yu, 2002, External economies in the international trade theory: a survey, Review of International Economics 10, 708-728.

[6] Guilló, M. and F. Pérez, 2003, The curse and blessing of fixed specific factors in small open economies, IVIE WP-AD 2003-36.

[7] Gylfason, T., T. Herbertsson and G. Zoega, 1999, A mixed blessing: natural resources and economic growth, Macroeconomic Dynamics 3, 204-225.

[8] Gylfason, T. and G. Zoega, 2001, Natural resources and economic growth: the role of investments, CEPR Discussion Paper 2743.

[9] Graham, B. and J. Temple, 2003, Rich nations, poor nations: How much can multiple equilibria explain? manuscript.

[10] Grossman, G. and E. Helpman, 2003, Technology and trade. In: G. Grossman, K. Rogoff, Eds., Handbook of International Economics (North-Holland), vol 3, Ch. 25.

[11] Hansen, G. and E. Prescott, 2002, Malthus to Solow, American Economic Review 60, 895-911. 
[12] Kemp, M. and A. Schweinberger, 1991, Variable returns to scale, nonuniqueness of equilibrium and the gains from international trade, Review of Economic Studies 58, 807-816.

[13] Kongsamut, P., S. Rebelo and D. Xie, 1997, Beyond balanced growth, NBER Working Paper 6159.

[14] Krugman, P., 1987, The narrow moving band, the dutch desease, and the competitive consequences of Mrs. Thatcher: Notes on trade in the presence of dynamic scale economics, Journal of Development Economics $27,41-55$.

[15] Lucas, R., 1988, On the mecanics of economic development. Journal of Monetary Economics 22, 3-42.

[16] Lucas, R., 1993, Making a miracle, Econometrica 61, 251-272.

[17] Maliar, L. and S. Maliar, 2003, The representative consumer in the neoclassical growth model with idiosyncratic shocks, Review of Economic Dynamics 6, 362-380.

[18] Matsuyama, K., 1991, Increasing returns, industrialization and indeterminacy of equilibrium, Quarterly Journal of Economics 106, 617-650.

[19] Matsuyama, K., 1992, Agricultural productivity, comparative advantage, and economic growth, Journal of Economic Theory 58, 317-334.

[20] Murphy, K., A. Schleifer and R. Vishny, 1989, Industrialization and the big push, Journal of Political Economy 97, 1003-1026.

[21] Park, J. and H. Ryu, 2003, Role of increasing returns in the East Asian economic growth, manuscript.

[22] Rodrick, D., 1996, Coordination failures and government policy: a model with application to East Asia and Eastern Europe, Journal of International Economics 40, 1-22.

[23] Rodrick, D., 2003, Growth strategies, In: P. Aghion and S. Durlauf, Eds., Handbook of Economic Growth, Ch. 5.

[24] Romer, P., 1986, Increasing returns and long-run growth, Journal of Political Economy 94, 1002-1037.

[25] Sachs, J. and A. Warner, 1995, Natural resource abundance and economic growth, NBER working paper 5398.

[26] Stockey, N., 1991, Human capital, product quality, and growth. Quarterly Journal of Economics 425, 587-616. 
[27] Ventura, J., 1997, Growth and interdependence, Quarterly Journal of Economics 112, 57-84.

[28] Young, A., 1991, Learning by doing and the dynamic effects of international trade, Quarterly Journal of Economics 105, 369-405. 
Table 1. Rankings of countries by GDP per capita in 1960 and in 1999 and by GDP growth over 1960-1999.

\begin{tabular}{|c|c|c|c|c|c|c|c|c|}
\hline \multirow{2}{*}{ Country } & \multicolumn{3}{|c|}{ Year 1960} & \multicolumn{3}{|c|}{ Year 1999} & \multirow{2}{*}{$\begin{array}{c}\text { GDP } \\
\text { growth } \\
\text { over } \\
1960- \\
1999^{\mathrm{b}}\end{array}$} & \multirow{2}{*}{$\begin{array}{c}\text { Rank by } \\
\text { GDP } \\
\text { growth } \\
\text { over } \\
1960- \\
1999\end{array}$} \\
\hline & Size & $\begin{array}{l}\text { GDP per } \\
\text { capita }^{\mathrm{a}}\end{array}$ & $\begin{array}{c}\text { Rank by } \\
\text { GDP }\end{array}$ & Size & $\begin{array}{l}\text { GDP per } \\
\text { capita }^{\mathrm{a}}\end{array}$ & $\begin{array}{c}\text { Rank by } \\
\text { GDP }\end{array}$ & & \\
\hline Botswana & 0.0025 & 343.57 & 82 & 0.0207 & 3611.00 & 45 & 10.5102 & 1 \\
\hline Singapore & 0.0669 & 2698.90 & 33 & 0.3583 & 25297.00 & 14 & 9.3731 & 2 \\
\hline South Korea & 0.4764 & 1255.60 & 47 & 1.8748 & 11022.00 & 28 & 8.7783 & 3 \\
\hline Malta & 0.0059 & 1177.30 & 48 & 0.0137 & 9759.50 & 29 & 8.2897 & 4 \\
\hline Oman & 0.0059 & 696.31 & 60 & 0.0575 & 5704.19 & 35 & 8.1920 & 5 \\
\hline Hong Kong, China & 0.1398 & 3007.60 & 29 & 0.5308 & 21801.00 & 17 & 7.2486 & 6 \\
\hline China & 1.1310 & 111.73 & 99 & 3.2980 & 724.73 & 72 & 6.4864 & 7 \\
\hline Thailand & 0.1866 & 465.92 & 73 & 0.5758 & 2628.50 & 50 & 5.6415 & 8 \\
\hline Japan & 11.7274 & 8213.50 & 17 & 19.5822 & 42285.00 & 3 & 5.1482 & 9 \\
\hline Malaysia & 0.1204 & 975.00 & 53 & 0.3559 & 4379.90 & 41 & 4.4922 & 10 \\
\hline Portugal & 0.3715 & 2737.30 & 32 & 0.4373 & 11976.00 & 27 & 4.3751 & 11 \\
\hline Ireland & 0.2347 & 5461.90 & 20 & 0.3149 & 23154.00 & 15 & 4.2392 & 12 \\
\hline Indonesia & 0.3556 & 249.34 & 87 & 0.7272 & 974.63 & 66 & 3.9088 & 13 \\
\hline Greece & 0.4257 & 3368.70 & 27 & 0.4726 & 12269.00 & 25 & 3.6421 & 14 \\
\hline Mauritius & 0.0112 & 1122.20 & 50 & 0.0171 & 4034.50 & 42 & 3.5952 & 15 \\
\hline Puerto Rico & 0.1204 & 3364.00 & 28 & 0.1701 & 12008.95 & 26 & 3.5698 & 16 \\
\hline Spain & 2.1352 & 4620.40 & 23 & 2.3642 & 16391.00 & 23 & 3.5475 & 17 \\
\hline Norway & 0.6117 & 11256.00 & 7 & 0.6016 & 37053.00 & 4 & 3.2918 & 18 \\
\hline Hungary & 0.2293 & 1513.60 & 42 & 0.1818 & 4907.80 & 37 & 3.2425 & 19 \\
\hline Egypt, Arab Rep. & 0.1415 & 359.67 & 79 & 0.2578 & 1143.60 & 63 & 3.1796 & 20 \\
\hline Luxembourg & 0.0754 & 15772.00 & 3 & 0.0775 & 49620.00 & 1 & 3.1461 & 21 \\
\hline Israel & 0.1686 & 5256.30 & 22 & 0.3597 & 16466.00 & 22 & 3.1326 & 22 \\
\hline Lesotho & 0.0022 & 168.47 & 96 & 0.0039 & 511.66 & 77 & 3.0371 & 23 \\
\hline Italy & 5.0629 & 6646.50 & 19 & 4.2005 & 19911.00 & 20 & 2.9957 & 24 \\
\hline Finland & 0.6646 & 9886.80 & 14 & 0.5523 & 29257.00 & 10 & 2.9592 & 25 \\
\hline Iceland & 0.0271 & 10135.00 & 12 & 0.0299 & 29809.00 & 8 & 2.9412 & 26 \\
\hline Austria & 1.1417 & 10675.00 & 9 & 0.9163 & 30962.00 & 6 & 2.9004 & 27 \\
\hline Sri Lanka & 0.0412 & 274.83 & 86 & 0.0543 & 789.30 & 70 & 2.8720 & 28 \\
\hline Belice & 0.0013 & 976.90 & 52 & 0.0024 & 2742.30 & 49 & 2.8071 & 29 \\
\hline Seychelles & 0.0016 & 2563.00 & 34 & 0.0021 & 7176.50 & 32 & 2.8000 & 30 \\
\hline Pakistan & 0.1257 & 180.66 & 94 & 0.2412 & 500.38 & 78 & 2.7697 & 31 \\
\hline Belgium & 1.4854 & 10735.00 & 8 & 1.0846 & 29016.00 & 11 & 2.7029 & 32 \\
\hline Barbados & 0.0102 & 2923.90 & 30 & 0.0077 & 7895.00 & 31 & 2.7002 & 33 \\
\hline Chile & 0.2272 & 1968.00 & 35 & 0.2849 & 5246.60 & 36 & 2.6660 & 34 \\
\hline France & 7.3557 & 10611.00 & 10 & 6.0421 & 28243.00 & 13 & 2.6617 & 35 \\
\hline Dominican Rep. & 0.0335 & 682.56 & 61 & 0.0545 & 1801.70 & 54 & 2.6396 & 36 \\
\hline Gabon & 0.0134 & 1810.70 & 39 & 0.0206 & 4768.10 & 38 & 2.6333 & 37 \\
\hline Brazil & 1.9228 & 1741.50 & 40 & 2.7340 & 4500.80 & 40 & 2.5844 & 38 \\
\hline Syrian Arab Rep. & 0.0329 & 475.16 & 72 & 0.0677 & 1206.60 & 62 & 2.5394 & 39 \\
\hline Trinidad and Tobago & 0.0242 & 1890.90 & 37 & 0.0219 & 4651.00 & 39 & 2.4597 & 40 \\
\hline Netherland & 2.0916 & 11999.00 & 6 & 1.6846 & 29293.00 & 9 & 2.4413 & 41 \\
\hline India & 1.2080 & 183.07 & 93 & 1.5449 & 430.46 & 81 & 2.3513 & 42 \\
\hline Australia & 1.5416 & 9887.20 & 13 & 1.5677 & 22821.00 & 16 & 2.3081 & 43 \\
\hline United States & 36.4050 & 13279.00 & 5 & 30.3477 & 30135.00 & 7 & 2.2694 & 44 \\
\hline Denmark & 1.1322 & 16287.00 & 2 & 0.7159 & 36864.00 & 5 & 2.2634 & 45 \\
\hline Canada & 2.5668 & 9329.94 & 16 & 2.3232 & 20967.00 & 18 & 2.2473 & 46 \\
\hline Panama & 0.0250 & 1462.50 & 43 & 0.0325 & 3206.10 & 48 & 2.1922 & 47 \\
\hline United Kingdom & 7.5467 & 9495.90 & 15 & 4.4976 & 20718.00 & 19 & 2.1818 & 48 \\
\hline Colombia & 0.2825 & 1104.20 & 51 & 0.3594 & 2404.40 & 52 & 2.1775 & 49 \\
\hline Mexico & 0.9189 & 1639.00 & 41 & 1.2352 & 3539.90 & 46 & 2.1598 & 50 \\
\hline Sweden & 1.5199 & 13390.00 & 4 & 0.9338 & 28796.00 & 12 & 2.1506 & 51 \\
\hline Paraguay & 0.0249 & 889.58 & 55 & 0.0342 & 1787.20 & 55 & 2.0090 & 52 \\
\hline Ecuador & 0.0523 & 776.68 & 57 & 0.0696 & 1559.80 & 58 & 2.0083 & 53 \\
\hline Morocco & 0.1229 & 696.40 & 59 & 0.1416 & 1391.80 & 61 & 1.9986 & 54 \\
\hline Costa Rica & 0.0344 & 1934.60 & 36 & 0.0486 & 3765.40 & 44 & 1.9463 & 55 \\
\hline Saudi Arabia & 0.2330 & 3767.70 & 25 & 0.4952 & 6866.00 & 33 & 1.8223 & 56 \\
\hline Fiji & 0.0084 & 1400.40 & 44 & 0.0072 & 2475.90 & 51 & 1.7680 & 57 \\
\hline Papua New Guinea & 0.0165 & 565.15 & 67 & 0.0168 & 998.59 & 65 & 1.7669 & 58 \\
\hline Switzerland & 2.1355 & 26245.00 & 1 & 1.1718 & 44988.00 & 2 & 1.7142 & 59 \\
\hline
\end{tabular}




\begin{tabular}{|c|c|c|c|c|c|c|c|c|}
\hline Kenya & 0.0254 & 201.20 & 92 & 0.0358 & 339.48 & 88 & 1.6873 & 60 \\
\hline Uruguay & 0.1492 & 3873.00 & 24 & 0.0778 & 6460.90 & 34 & 1.6682 & 61 \\
\hline Guatemala & 0.0558 & 928.30 & 54 & 0.0606 & 1531.10 & 60 & 1.6494 & 62 \\
\hline Mauritania & 0.0044 & 293.87 & 83 & 0.0044 & 476.87 & 79 & 1.6227 & 63 \\
\hline Bahamas, The & 0.0134 & 7842.40 & 18 & 0.0137 & 12696.00 & 24 & 1.6189 & 64 \\
\hline Bangladesh & 0.1697 & 217.46 & 91 & 0.1613 & 350.38 & 86 & 1.6112 & 65 \\
\hline New Zealand & 0.3728 & 10356.00 & 11 & 0.2301 & 16564.00 & 21 & 1.5995 & 66 \\
\hline Congo, Rep. & 0.0084 & 557.32 & 68 & 0.0091 & 889.85 & 68 & 1.5967 & 67 \\
\hline Philippines & 0.2975 & 711.40 & 58 & 0.3000 & 1123.80 & 64 & 1.5797 & 68 \\
\hline Malawi & 0.0052 & 97.79 & 100 & 0.0059 & 154.09 & 97 & 1.5757 & 69 \\
\hline Zimbabwe & 0.0264 & 455.59 & 75 & 0.0306 & 715.34 & 74 & 1.5701 & 70 \\
\hline Argentina & 1.6965 & 5423.20 & 21 & 1.1214 & 8473.60 & 30 & 1.5625 & 71 \\
\hline Burkina Faso & 0.0119 & 169.13 & 95 & 0.0102 & 258.66 & 90 & 1.5294 & 72 \\
\hline Nepal & 0.0208 & 147.66 & 97 & 0.0183 & 218.79 & 95 & 1.4817 & 73 \\
\hline Togo & 0.0053 & 230.20 & 88 & 0.0054 & 328.11 & 89 & 1.4253 & 74 \\
\hline Honduras & 0.0147 & 513.17 & 71 & 0.0163 & 721.70 & 73 & 1.4064 & 75 \\
\hline South Africa & 0.7472 & 2830.60 & 31 & 0.5948 & 3921.80 & 43 & 1.3855 & 76 \\
\hline Algeria & 0.1876 & 1145.00 & 49 & 0.1667 & 1541.80 & 59 & 1.3466 & 77 \\
\hline Cote d'Ivoire & 0.0337 & 587.02 & 66 & 0.0436 & 786.45 & 71 & 1.3397 & 78 \\
\hline El Salvador & 0.0513 & 1310.40 & 46 & 0.0382 & 1727.40 & 56 & 1.3182 & 79 \\
\hline Peru & 0.2823 & 1873.10 & 38 & 0.2139 & 2353.70 & 53 & 1.2566 & 80 \\
\hline Cameroon & 0.0416 & 518.24 & 70 & 0.0338 & 645.53 & 75 & 1.2456 & 81 \\
\hline Jamaica & 0.0346 & 1398.00 & 45 & 0.0162 & 1712.00 & 57 & 1.2246 & 82 \\
\hline Guyana & 0.0058 & 676.95 & 62 & 0.0026 & 824.44 & 69 & 1.2179 & 83 \\
\hline Bolivia & 0.0420 & 826.66 & 56 & 0.0283 & 972.24 & 67 & 1.1761 & 84 \\
\hline Burundi & 0.0057 & 128.09 & 98 & 0.0035 & 147.25 & 99 & 1.1496 & 85 \\
\hline Nigeria & 0.1385 & 223.53 & 89 & 0.1123 & 253.70 & 91 & 1.1350 & 86 \\
\hline Benin & 0.0109 & 350.65 & 80 & 0.0086 & 393.90 & 83 & 1.1233 & 87 \\
\hline Venezuela & 0.4279 & 3720.50 & 26 & 0.3006 & 3531.00 & 47 & 0.9491 & 88 \\
\hline Ghana & 0.0462 & 449.53 & 76 & 0.0270 & 401.28 & 82 & 0.8927 & 89 \\
\hline Senegal & 0.0324 & 670.38 & 63 & 0.0191 & 577.51 & 76 & 0.8615 & 90 \\
\hline Rwanda & 0.0115 & 276.28 & 85 & 0.0067 & 226.94 & 93 & 0.8214 & 91 \\
\hline Chad & 0.0135 & 289.63 & 84 & 0.0060 & 225.51 & 94 & 0.7786 & 92 \\
\hline Central African Rep. & 0.0106 & 457.45 & 74 & 0.0043 & 341.20 & 87 & 0.7459 & 93 \\
\hline Sierra Leone & 0.0075 & 219.33 & 90 & 0.0027 & 153.08 & 98 & 0.6979 & 94 \\
\hline Nicaragua & 0.0153 & 655.54 & 64 & 0.0079 & 452.22 & 80 & 0.6898 & 95 \\
\hline Haiti & 0.0316 & 546.91 & 69 & 0.0104 & 369.96 & 85 & 0.6765 & 96 \\
\hline Madagascar & 0.0312 & 382.67 & 78 & 0.0127 & 238.40 & 92 & 0.6230 & 97 \\
\hline Zambia & 0.0309 & 647.79 & 65 & 0.0137 & 387.92 & 84 & 0.5988 & 98 \\
\hline Niger & 0.0186 & 405.33 & 77 & 0.0081 & 217.52 & 96 & 0.5366 & 99 \\
\hline Congo, Dem. Rep. & 0.0813 & 349.56 & 81 & 0.0193 & 112.66 & 100 & 0.3223 & 100 \\
\hline
\end{tabular}

Note: ${ }^{\text {a }}$ GDP per capita is expressed in 1995US\$.

${ }^{\mathrm{b}}$ GDP growth over 1960-1999 is defined as the ratio of GDP per capita in 1999 to GDP per capita in 1960. 
Table 2. Selected statistics on GDP, its components and export for different groups of countries.

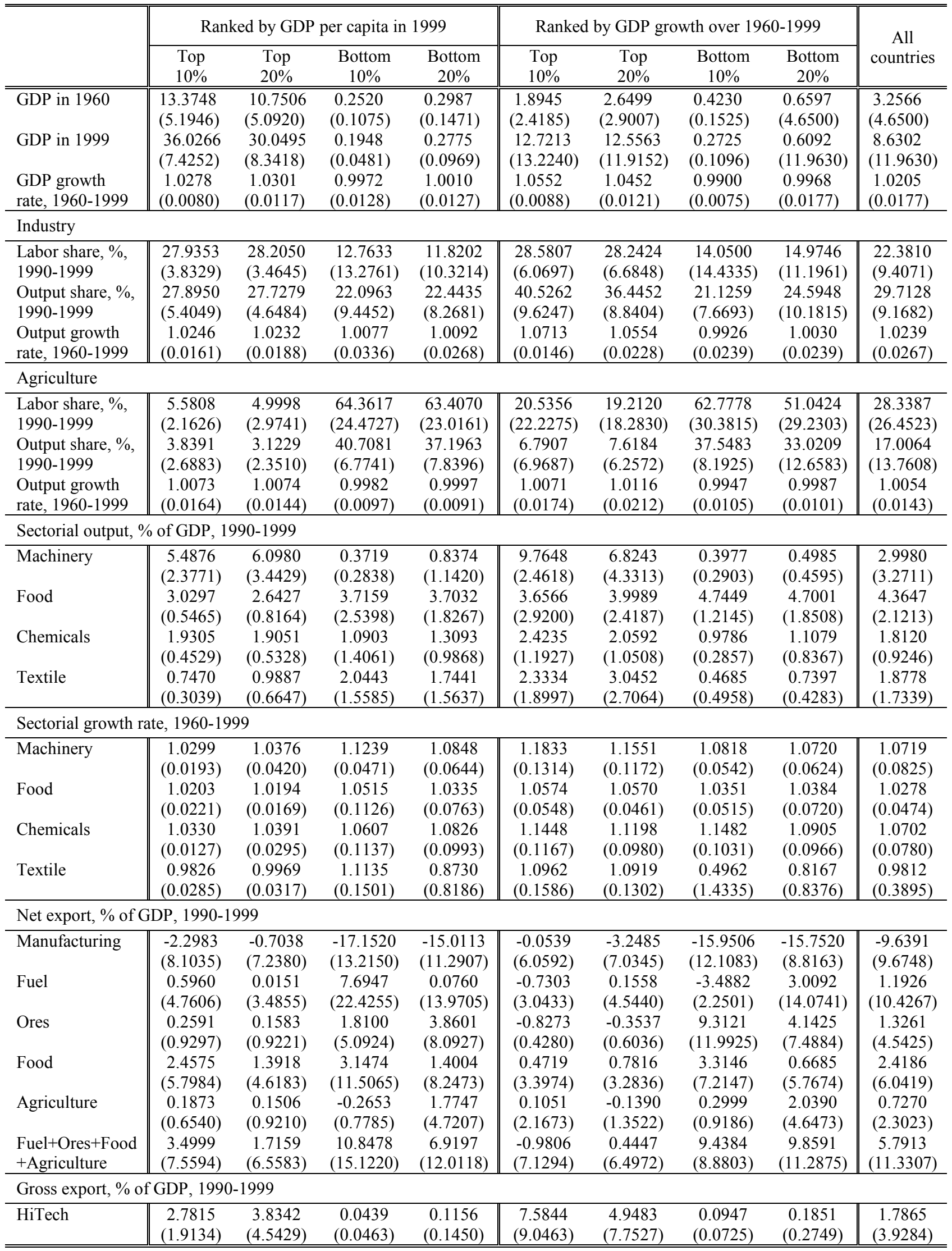

Note: Numbers in each column are the group-averages and numbers in parenthesis are the group-standard deviations of the corresponing statistics. 
Table 3. The main exported and imported products for the three groups of countries.

\begin{tabular}{|c|c|c|}
\hline Country & Export & Import \\
\hline \multicolumn{3}{|l|}{ The rich group } \\
\hline Luxembourg & $\begin{array}{l}\text { machinery and equipment, steel products, chemicals, rubber } \\
\text { products, glass }\end{array}$ & minerals, metals, foodstuffs, quality consumer goods \\
\hline Switzerland & machinery, chemicals, metals, watches, agricultural products & $\begin{array}{l}\text { machinery, chemicals, vehicles, metals; agricultural products, } \\
\text { textiles }\end{array}$ \\
\hline Japan & motor vehicles, semiconductors, office machinery, chemicals & $\begin{array}{l}\text { machinery and equipment, fuels, foodstuffs, chemicals, } \\
\text { textiles, raw materials (2001) }\end{array}$ \\
\hline Norway & $\begin{array}{l}\text { petroleum and petroleum products, machinery and equipment, } \\
\text { metals, chemicals, ships, fish }\end{array}$ & machinery and equipment, chemicals, metals, foodstuffs \\
\hline Denmark & $\begin{array}{l}\text { machinery and instruments, meat and meat products, dairy } \\
\text { products, fish, chemicals, furniture, ships, windmills }\end{array}$ & $\begin{array}{l}\text { machinery and equipment, raw materials and } \\
\text { semimanufactures for industry, chemicals, grain and } \\
\text { foodstuffs, consumer goods }\end{array}$ \\
\hline Austria & $\begin{array}{l}\text { machinery and equipment, motor vehicles and parts, paper and } \\
\text { paperboard, metal goods, chemicals, iron and steel; textiles, } \\
\text { foodstuffs }\end{array}$ & $\begin{array}{l}\text { machinery and equipment, motor vehicles, chemicals, metal } \\
\text { goods, oil and oil products; foodstuffs }\end{array}$ \\
\hline United & capital goods, automobiles, industrial supplies and raw & crude oil and refined petroleum products, machinery, \\
\hline States & materials, consumer goods, agricultural products & $\begin{array}{l}\text { automobiles, consumer goods, industrial raw materials, food } \\
\text { and beverages }\end{array}$ \\
\hline Iceland & $\begin{array}{l}\text { fish and fish products } 70 \% \text {, animal products, aluminum, } \\
\text { diatomite, ferrosilicon }\end{array}$ & $\begin{array}{l}\text { machinery and equipment, petroleum products; foodstuffs, } \\
\text { textiles }\end{array}$ \\
\hline Netherland & machinery and equipment, chemicals, fuels; foodstuffs & $\begin{array}{l}\text { machinery and transport equipment, chemicals, fuels; } \\
\text { foodstuffs, clothing }\end{array}$ \\
\hline Finland & $\begin{array}{l}\text { machinery and equipment, chemicals, metals; timber, paper, } \\
\text { pulp (1999) }\end{array}$ & $\begin{array}{l}\text { foodstuffs, petroleum and petroleum products, chemicals, } \\
\text { transport equipment, iron and steel, machinery, textile yarn } \\
\text { and fabrics, grains (1999) }\end{array}$ \\
\hline \multicolumn{3}{|c|}{ The fast-growing group } \\
\hline Botswana & diamonds $90 \%$, copper, nickel, soda ash, meat, textiles & $\begin{array}{l}\text { foodstuffs, machinery, electrical goods, transport equipment, } \\
\text { textiles, fuel and petroleum products, wood and paper } \\
\text { products, metal and metal products }\end{array}$ \\
\hline Singapore & $\begin{array}{l}\text { machinery and equipment (including electronics), consumer } \\
\text { goods, chemicals, mineral fuels }\end{array}$ & $\begin{array}{l}\text { machinery and equipment, mineral fuels, chemicals, } \\
\text { foodstuffs }\end{array}$ \\
\hline South Korea & $\begin{array}{l}\text { electronic products, machinery and equipment, motor } \\
\text { vehicles, steel, ships; textiles, clothing, footwear; fish }\end{array}$ & $\begin{array}{l}\text { machinery, electronics and electronic equipment, oil, steel, } \\
\text { transport equipment, textiles, organic chemicals, grains }\end{array}$ \\
\hline Malta & machinery and transport equipment, manufactures & $\begin{array}{l}\text { machinery and transport equipment, manufactured and semi- } \\
\text { manufactured goods; food, drink, and tobacco }\end{array}$ \\
\hline Oman & petroleum, reexports, fish, metals, textiles & $\begin{array}{l}\text { machinery and transport equipment, manufactured goods, } \\
\text { food, livestock, lubricants }\end{array}$ \\
\hline Hong Kong & $\begin{array}{l}\text { electrical machinery and appliances, textiles, apparel, } \\
\text { footwear, watches and clocks, toys, plastics, precious stones }\end{array}$ & $\begin{array}{l}\text { foodstuffs, transport equipment, raw materials, } \\
\text { semimanufactures, petroleum, plastics, machinery, electrical } \\
\text { equipment; a large share is reexported }\end{array}$ \\
\hline China & $\begin{array}{l}\text { machinery and equipment; textiles and clothing, footwear, } \\
\text { toys and sporting goods; mineral fuels }\end{array}$ & $\begin{array}{l}\text { machinery and equipment, mineral fuels, plastics, iron and } \\
\text { steel, chemicals }\end{array}$ \\
\hline Thailand & computers, transistors, seafood, clothing, rice (2000) & $\begin{array}{l}\text { capital goods, intermediate goods and raw materials, } \\
\text { consumer goods, fuels }(2000)\end{array}$ \\
\hline Malaysia & $\begin{array}{l}\text { electronic equipment, petroleum and liquefied natural gas, } \\
\text { wood and wood products, palm oil, rubber, textiles, chemicals } \\
(2000)\end{array}$ & $\begin{array}{l}\text { electronics, machinery, petroleum products, plastics, vehicles, } \\
\text { iron and steel products, chemicals (2000) }\end{array}$ \\
\hline \multicolumn{3}{|c|}{ The poor group } \\
\hline Nigeria & petroleum and petroleum products $95 \%$, cocoa, rubber & $\begin{array}{l}\text { machinery, chemicals, transport equipment, manufactured } \\
\text { goods, food and live animals }\end{array}$ \\
\hline Madagascar & $\begin{array}{l}\text { coffee, vanilla, shellfish, sugar; cotton cloth, chromite, } \\
\text { petroleum products }\end{array}$ & capital goods, petroleum, consumer goods, food \\
\hline Rwanda & coffee, tea, hides, tin ore & $\begin{array}{l}\text { foodstuffs, machinery and equipment, steel, petroleum } \\
\text { products, cement and construction material }\end{array}$ \\
\hline Chad & cotton, cattle, gum arabic & $\begin{array}{l}\text { machinery and transportation equipment, industrial goods, } \\
\text { petroleum products, foodstuffs, textiles }\end{array}$ \\
\hline Nepal & carpets, clothing, leather goods, jute goods, grain & gold, machinery and equipment, petroleum products, fertilizer \\
\hline Níger & uranium ore, livestock, cowpeas, onions & foodstuffs, machinery, vehicles and parts, petroleum, cereals \\
\hline Malawi & $\begin{array}{l}\text { tobacco } 60 \% \text {, tea, sugar, cotton, coffee, peanuts, wood } \\
\text { products, apparel }\end{array}$ & $\begin{array}{l}\text { food, petroleum products, semimanufactures, consumer goods, } \\
\text { transportation equipment }\end{array}$ \\
\hline Sierra Leone & diamonds, rutile, cocoa, coffee, fish (1999) & $\begin{array}{l}\text { foodstuffs, machinery and equipment, fuels and lubricants, } \\
\text { chemicals (1995) }\end{array}$ \\
\hline Burundi & coffee, tea, sugar, cotton, hides & capital goods, petroleum products, foodstuffs \\
\hline Congo, D. R. & diamonds, copper, crude oil, coffee, cobalt & $\begin{array}{l}\text { foodstuffs, mining and other machinery, transport equipment, } \\
\text { fuels }\end{array}$ \\
\hline
\end{tabular}

Note: Exported and imported are provided starting from the most important. 
Figure 1. Shares of industry and agriculture in GDP for three groups of countries.

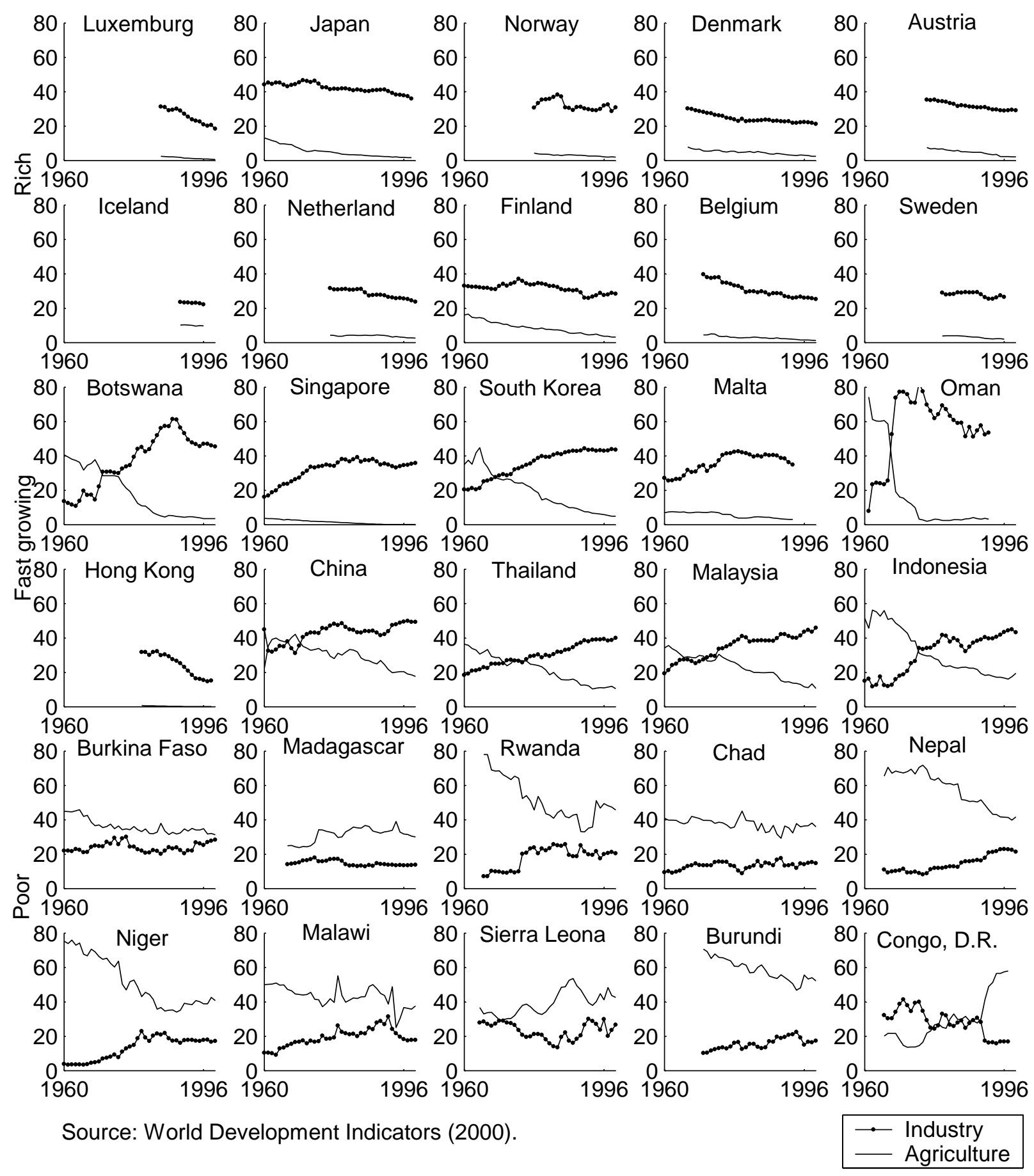


Figure 2. Sectorial composition of manufacturing for three groups of countries.
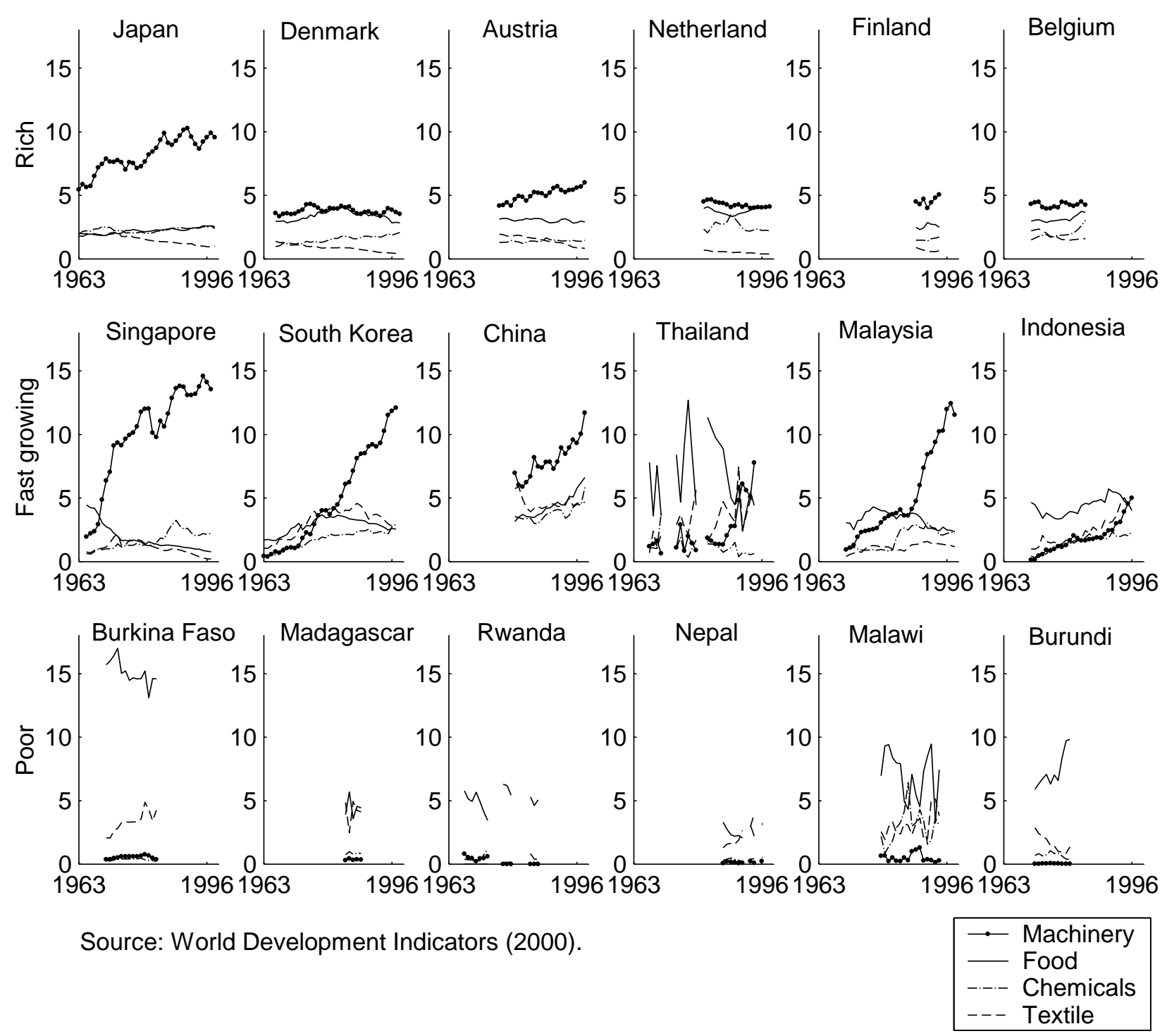
Figure 3. Sectorial composition of net export for three groups of countries.
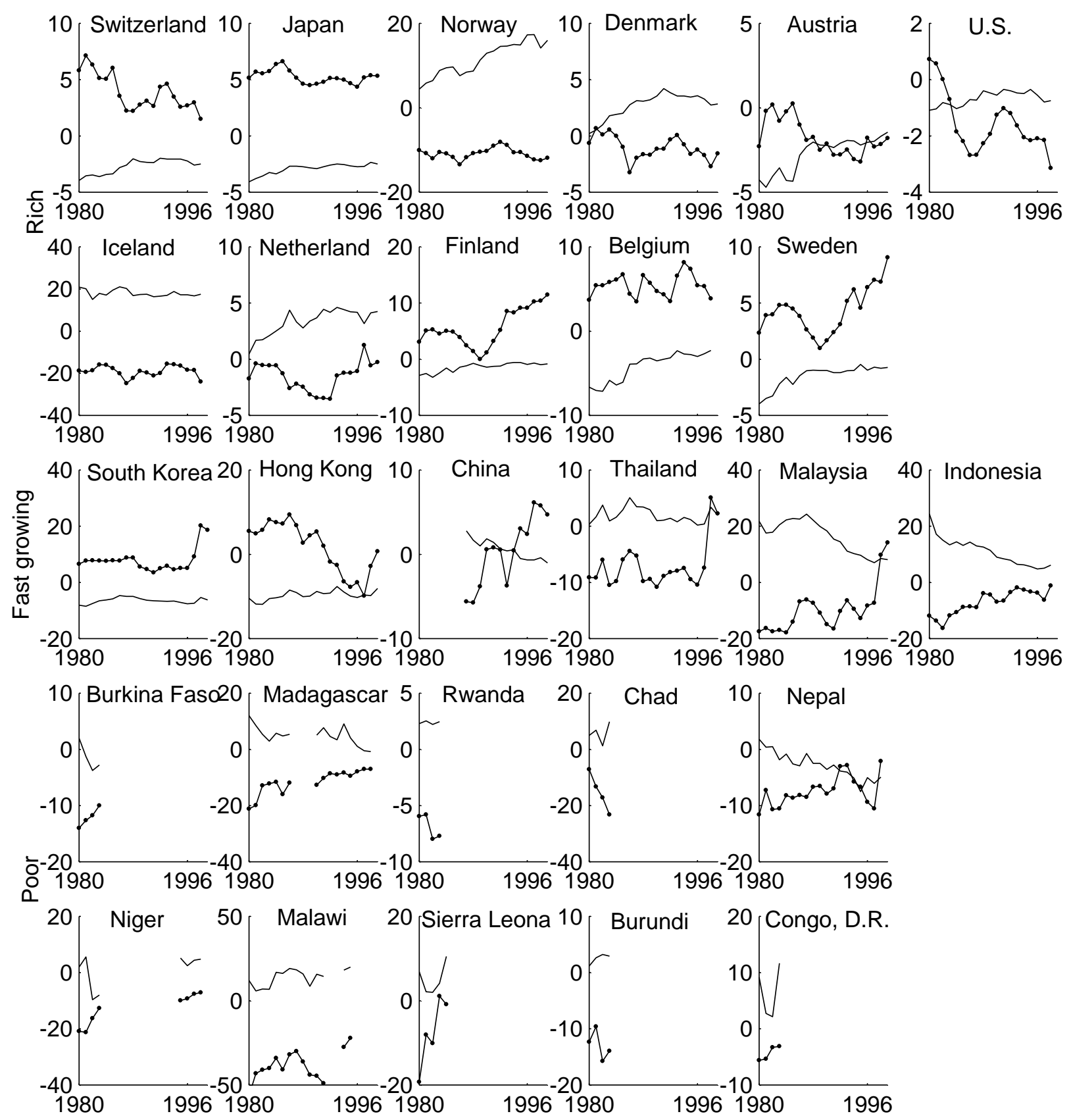

\section{- Net export of fuel, ores, food and agricalture, \% of GDP}

$\rightarrow$ Net export of manufacturing, \% of GDP

Source: World Development Indicators (2000). 
Figure 4. Equilibria I, II and III and threshold value $\bar{k}$ in the open economy.

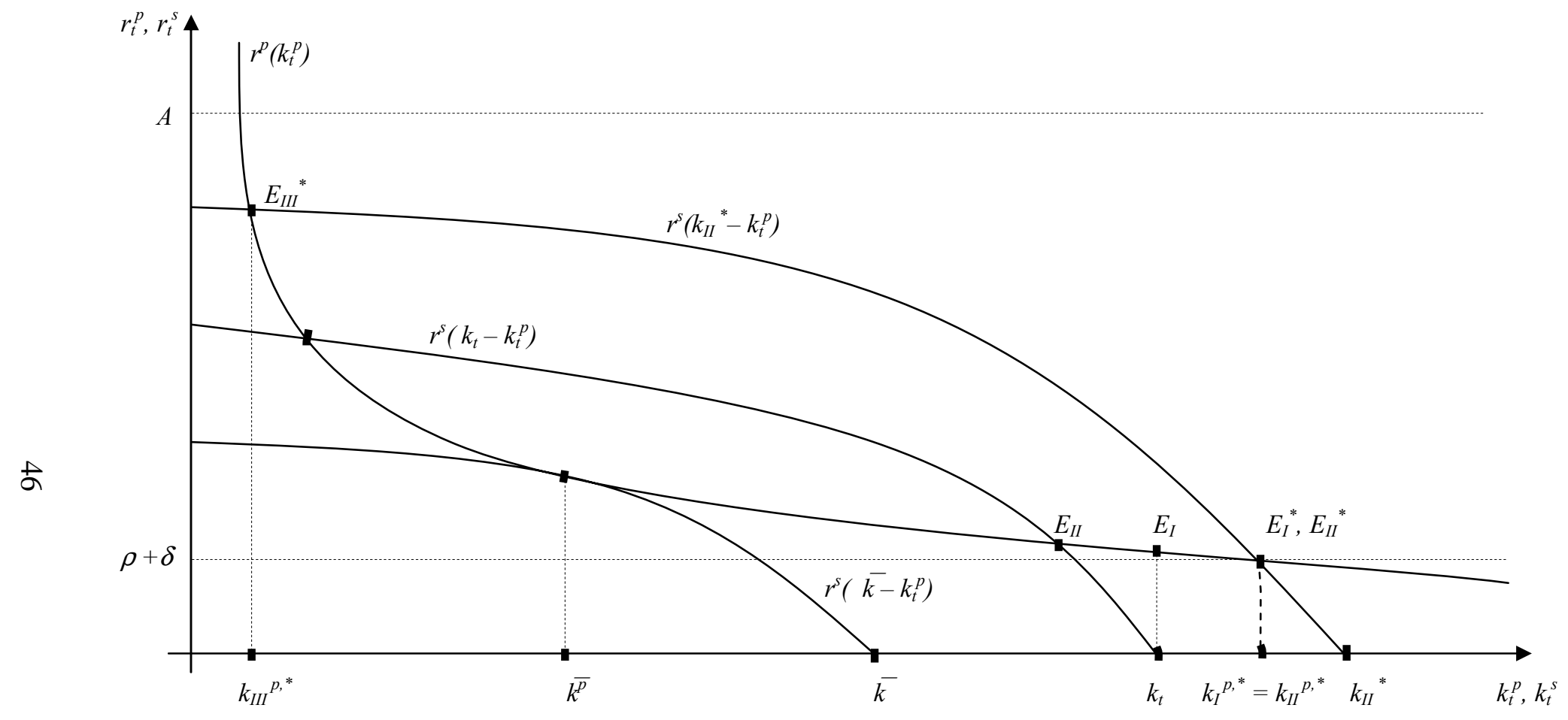

